\title{
Genetic control of pod dehiscence in domesticated common bean: Associations with range expansion and local aridity conditions
}

Travis A. Parker, Jorge C. Berny Mier y Teran, Antonia Palkovic, Judy Jernstedt, and Paul Gepts $^{1}$

University of California, Department of Plant Sciences, 1 Shields Avenue, Davis, CA 95616-8780.

Classification

Major category: BIOLOGICAL SCIENCES

Minor category: Agricultural Sciences

Keywords: dirigent | aridity tolerance | GWAS | local adaptation | pod shattering

Author contributions: T.A.P. prepared the manuscript and conducted laboratory phenotyping, QTL mapping, GWAS, microscopy, and sequencing. J.C.B.M.T. genotyped the IxS population, gathered field phenotypes, co-conducted QTL mapping, and provided guidance for other procedures. A.P. assisted with field and greenhouse trials. J.J. led the sectioning and microscopy studies. P.G. conceived the initial project and provided guidance. All authors edited the manuscript.

The authors declare no conflict of interest.

Data deposition: The coding DNA sequence of PvPdh1 for ICA Bunsi and SXB 405 will be deposited in the $\mathrm{NCBI}$ database.

${ }^{1}$ To whom correspondence should be addressed. Email: plgepts@ucdavis.edu. Phone: 1 (530) 752-7743. 
1 Significance

2 Plant domestication has radically modified crop morphology and development.

3 Nevertheless, many crops continue to display some atavistic characteristics that were

4 advantageous to their wild ancestors, such as pod dehiscence (PD). Domesticated

5 common bean (Phaseolus vulgaris), a nutritional staple for millions of people globally,

6 shows considerable variation in PD. Here, we identified multiple genetic regions

7 controlling PD in common bean grown throughout geographically distributed lineages.

8 For example, on chromosome Pv03, PvPdh1 shows a single base-pair substitution that is

9 strongly associated with decreased PD and expansion of the crop into northern Mexico,

10 where the arid conditions promote PD. The environmental dependency and genetic

11 redundancy explain the maintenance of atavistic traits under domestication. Knowledge

12 of PD genetics will assist in developing aridity-adapted varieties.

\section{Abstract}

15 A reduction in pod dehiscence (PD) is an important part of the domestication syndrome in legumes, including common bean. Despite this, many modern dry bean varieties continue to suffer yield reductions due to dehiscence, an atavistic trait, which is particularly problematic in hot, dry environments. To date, the genetic control of this important trait has been only partially resolved. Using QTL mapping and GWAS, we identified major PD QTLs in dry beans on chromosomes Pv03, Pv05, Pv08, and Pv09, three of which had not been described previously. We further determined that the QTL on chromosome Pv03, which is strongly associated with PD in Middle American beans, includes a dirigent-like candidate gene orthologous to Pod dehiscence 1 (Pdh1) of soybean. In this gene, we identified a substitution in a highly conserved amino acid that is unique to PD-resistant varieties. This allele is associated with the expansion of Middle American domesticated common beans into the arid environments of northern Mexico, resulting in a high allelic frequency in the domesticated ecogeographic race Durango.

The polygenic redundancy and environmental dependency of PD resistance may explain

29 the maintenance of this atavistic characteristic after domestication. Use of these alleles

30 in breeding will reduce yield losses in arid growing conditions, which are predicted to

31 become more widespread in coming decades. 
34 Ibody

35 Introduction

Effective seed dispersal is vital for spermatophytes. In the Fabaceae, the third largest family of

38 flowering plants (1), seed dispersal is typically mediated by the explosive dehiscence

39 ("shattering") of pods at maturity. This mechanism is effective for the propagation of plants in the wild, but is associated with reduced yield and harvest constraints for cultivated crops. As such, there has been selection against pod dehiscence (PD), which continues to this day. A

42 reduction in PD has been a central part of the domestication syndrome of many domesticated

43 pulses. Anatomical differences are associated with some, but not all variation in PD in these

44 species $(2,3)$. Reviews of the developmental genetics related to PD are available $(4,5)$.

In soybean (Glycine max (L.) Merr.), a domestication-related reduction in PD is mediated by the NAC family transcription factor SHAT1-5 (6). A further reduction in PD is controlled by

47 Pod dehiscence 1 (Pdhl) (7). Pdhl encodes a dirigent-like gene related to lignin synthesis. This

48 mutation is associated with the expansion of soybeans into arid regions. Pdhl is highly expressed

49 in obliquely oriented fibers lining the soybean pod walls and has a minimal effect on gross pod 50 anatomy (8).

Common bean (Phaseolus vulgaris L.) is the foremost grain legume for direct human

52 consumption and is a dietary staple for hundreds of millions of people worldwide (9). Common

53 bean diverged into distinct Middle American and Andean gene pools approximately 87,000 years

54 before present, well before the first human migrations into the Americas (10). Subsequently,

55 human populations independently domesticated members of each gene pool, making up two of at

56 least seven domestication events in the genus Phaseolus (11) and 41 domestication events in the

57 Fabaceae (12). Each of the two major domesticated gene pools of common bean is divided into

58 several ecogeographic races. In the Middle American domesticated gene pool, it is important to

59 single out race Durango, which includes varieties from arid, higher altitude regions of northern

60 Mexico, and race Mesoamerica, from the warmer, humid lowlands of southern Mexico and

61 Central America (13).

62 Phaseolus vulgaris can be separated into two economic groups: snap beans, grown for

63 pods as a vegetable, and dry beans, grown for grain. Dry beans produce fibrous pods, which can

64 be easily separated from seeds during threshing. In snap beans, selections in the $19^{\text {th }}$ century led

65 to "stringless" varieties with extreme PD resistance and very little pod suture fiber deposition 
(14). Stringless varieties now dominate the snap bean market, but stringlessness is absent in dry beans. Using a recombinant inbred (RI) population derived from stringless cv. 'Midas' and wild accession G12873, Koinange et al. (15) identified a major pod fiber QTL on linkage group Pv02 (16). This gene, called Stringless (St), maps near the common bean ortholog of INDEHISCENT $(P v I N D)$, but there is a lack of complete co-segregation between the loci and no causal polymorphism is known to exist in the PvIND sequence (17). Rau et al. (18) used QTL mapping to identify a segregating locus on Pv05 in the Midas x G12873 genetic background. Despite this, a comprehensive evaluation of the genetic basis of PD in diverse germplasm has not yet been conducted and no molecular polymorphisms with a potential causal effect on PD have been

75 described.

In the research reported here, we used high-precision phenotyping techniques, both in an RI population and diversity panels, to identify PD QTLs in common bean. A locus underlying one of the major QTLs was sequenced to identify possible causal polymorphisms. We found orthologous mechanisms that regulate pod dehiscence in this species. We were further able to identify associations between PD and local environmental conditions. Alleles identified in this study will be valuable for developing common bean varieties suited to the increasingly arid climatic conditions of coming decades.

\section{Results}

Anatomical analysis of developing pods. Clear differences in pod anatomy were found beans produce a lignified wall fiber layer (LFL) in the pods that is thicker than the bundle cap layer, while the LFL is greatly reduced in domesticated varieties. Stringless snap beans have weakly lignified vascular bundle sheaths (VS) at the suture, with a reduction in the number of lignified cells and the extent of secondary cell wall deposition in each cell. In stringless beans,

93 groups, no variation between PD-resistant and PD-susceptible domesticated dry bean pods was

94 observed (Fig. 1B, 1C).

96 Variation in the ICA Bunsi/SXB 405 (IXS) population. Segregation for PD was

97 determined in an RI population derived from PD-susceptible cv. 'ICA Bunsi' and PD-resistant 
cv. 'SXB 405'. Both parental genotypes belong to the Middle American gene pool. Three phenotyping approaches were used to evaluate PD (Fig. S1) and each had a unique distribution pattern (Fig. S2). These phenotypes were strongly correlated (Fig. S3). Varieties that dehisced in the field had higher rates of $\mathrm{PD}$ after desiccation at $65^{\circ} \mathrm{C}$ (two-tailed t-test, $\mathrm{p}=3.1^{*} 10^{-8}$ ) and required lower levels of force to induce fracture at the sutures (two-tailed t-test, $\mathrm{p}=1.2^{*} 10^{-9}$ ). Similarly, the proportion dehiscing in the desiccator and force required to cause PD were negatively correlated $\left(\mathrm{r}^{2}=0.71\right.$ simple linear model, $\left.\mathrm{p}<2 * 10^{-16}\right)$.

QTL mapping identified a major, PD-related QTL peak located in the same position on linkage group Pv03 using each of the three phenotyping methods (Fig. 2). The QTL mapped between SNP markers ss715639553 and ss715639323, which are separated by approximately $900 \mathrm{~kb}$ of physical distance (Table 1). Force measurement produced the most significant results (LOD score 53.3), followed by desiccation (LOD score 42.7), and field notes (LOD score 8.9). All methods produced results that were statistically significant based on 1000 randomized permutations of the data. The allele at the most significant SNP explained $17 \%$ of the variation in PD based on field notes, $59 \%$ of the variation based on desiccation, and $64 \%$ of the variation in force required for fracture in the population. Analyses to find additional PD QTLs failed to identify other regions of interest in the IxS population.

Synteny mapping and expression. Due to the close phylogenetic relationship and extensive microsynteny between $P$. vulgaris and $G$. $\max (19,20)$, gene families known to affect PD in soybean were primary candidates for control of the trait in common bean. These families include the $N A C$-domain transcription factors and dirigent-like genes.

No $N A C$-domain transcription factors exist in the Pv03 QTL mapping interval. In contrast, the LegumeIP 2.0 synteny tool indicated that strong synteny exists between the soybean region surrounding GmPdh1 and the common bean QTL (Table S3). This is in agreement with previous synteny analyses $(20,21)$. An amino acid BLAST of GmPDH1 (cv. Toyosume) against the $P$. vulgaris G19833 proteome (21) indicates that the most similar common bean protein is encoded by Phvul.003G252100, which maps between the two most significant Pv03 QTL SNP markers. A neighbor-joining tree of common bean and soybean dirigent proteins indicates that

127 GmPDH1 and the protein product of Phvul.003G252100 cluster together (Fig. S4). Furthermore, the common bean gene's expression is limited to developing pods, with no detectable expression 
129 in any other tissues (Fig. S5; data from (22)). This is comparable to the expression of soybean

$130 \mathrm{PDH}$ (7), and indicates that the gene serves a function unique to pods. Together, these results

131 suggest that Phvul.003G252100 is orthologous to GmPDH1. Phvul.003G252100 is hereafter

132 referred to as $P v P d h 1$.

Sequencing of PvPdh1. Sequencing of $P v P d h 1$ in ICA Bunsi and SXB 405 revealed a nonsynonymous single-base-pair substitution at position 485 of the gene's coding sequence (Fig. S6A). This substitution leads to a threonine/asparagine polymorphism (T162N) in the protein product (Fig. S6B). The 11 RILs with recombination between the most significant markers from QTL mapping showed complete co-segregation between the threonine/asparagine polymorphism and the PD phenotype (Table S1).

To investigate the functional importance of T162N, we evaluated the extent of its sequence conservation, surveyed literature related to this position in closely related dirigent

142 proteins and used software tools to predict the effect of this substitution at the position.

143 Sequencing of $P v P d h 1$ in several species of wild and domesticated Phaseolus from the USDA

144 National Plant Germplasm System (NPGS) and UC Davis showed that the asparagine at this

145 position was unique to the Middle American domesticated gene pool (Table S2). No

146 polymorphism in the Andean gene pool was consistently associated with PD. In the Middle

147 American gene pool, PD was significantly higher among genotypes with a threonine at position

148162 than an asparagine (t-test: $\mathrm{p}=0.0002, \mathrm{n}=47$, Fig. S7). This threonine was strictly conserved in

149 Andean domesticated common bean, Middle American and Andean wild common bean, and the 150 closely related P. lunatus and P. dumosus (Table S2). The residue is present in 99 of the 100 151 most similar proteins in the NCBI database (Fig. S8A; see Discussion), indicating its functional 152 importance. This threonine is also conserved in the 19 most similar proteins of Selaginella 153 moellendorffii (Fig. S8B), a member of the first diverging group of lignin-containing plants. No 154 comparable protein could be found in the proteome of Physcomitrella patens, a non-lignified 155 moss.

Studies of closely related dirigent proteins indicate that this threonine is a component of 157 one of the protein's active sites (“T163” in Fig. S8C; from (23)), and its substitution eliminates 158 protein function (Fig. S8D; from (24)). An analysis with PROVEAN (25) predicted that the 159 T162N mutation would have a deleterious effect (score: -4.587 , cutoff $=-2.5$ ). 
Validation through association mapping. The BeanCAP Middle American Diversity Panel (MDP) (26) was grown to determine, using the desiccation method, whether the Pv03 PvPdh1 locus was related to PD in a broader population. A genome-wide association study (GWAS) indicated that the SNP closest to $P v P d h 1$ in physical distance was also the most significantly associated with PD (Fig. 3A, MAF threshold=0.1). This SNP (S1_149243152) was $5.7 \mathrm{~kb}$ from the polymorphism in $P v P d h 1$. Pv06 and Pv08 also included loci significantly associated with PD.

GWAS was also conducted in the Andean diversity panel (ADP) (27) to determine which loci control PD in this independently domesticated population. Chromosomes Pv03, Pv05, Pv08, and Pv09 all included major regions significantly associated with PD (Fig. 3B). The QTL on chromosome Pv08 was in an overlapping physical position with a QTL from the MDP (Fig. 3A).

In both the Andean and Middle American gene pools, PD varied greatly between market classes (Table S4). In Andean beans, PD after desiccation averaged 3\% in the purple speck market class and $41 \%$ in the cranberry types. In Middle American beans, averages were below $1 \%$ for pinto types of race Durango, and as high as $18 \%$ in the black beans of race Mesoamerica. Members of Middle American race Mesoamerica displayed considerable variation in PD. GWAS using only members of this race (MDP with PC1 > 50) showed that the Pv08 QTL was most closely associated with PD in the population (Fig. S9). SNP S1_329543689, near the center of this interval of interest, was used for subsequent analyses. The region near $P v P d h 1$ did not include significant SNPs in this race, further indicating that races Durango and Mesoamerica rely on different genes for PD resistance.

To visualize the correlation between PD and population substructure in the MDP, PD was plotted against the first principal component of the genetic data. Each point was color-coded by its allele at the GWAS SNP peaks on Pv03 (S1_149243152, 5.7kb from PvPdh1) and Pv08 (SNP S1_329543689) (Fig. 4). Members of the MDP with the Pv03 PD resistance allele exhibited mean PD in the desiccator of 0.0067 , with a maximum value of 0.14 . In genotypes with no known resistance allele, the mean level of PD was 0.206 and ranged up to 0.63 (Fig. 4). 


\section{Discussion}

A reduction in PD is a fundamental component of the domestication syndrome in common bean (15), and is important for future green and dry bean production and food security. In snap beans, a major gene - St controls the presence or absence of pod strings and PD (Prakken, 1934; Koinange et al. 1996). For dry beans, we report here three novel QTLs mapped for the trait (on Pv03, Pv08, and Pv09), confirm a QTL on Pv05, identify a putative causal polymorphism in the $P v P d h 1$ gene underlying the major QTL on Pv03, and describe the association between Pv03, Pv05, and Pv08 QTLs and climate variables, especially precipitation.

\section{Anatomical differences among wild and domesticated types. Our microscopy results are} consistent with those of previous researchers, who noted that reduced lignification in the LFL is correlated with reduced PD among wild beans, domesticated dry beans, and domesticated snap beans (2, $3,28)$. However, we were not able to identify anatomical differences responsible for the variation in dehiscence among dry bean cultivars. This is consistent with the pattern seen in GmPdhl in soybean (8) and the expected result of a mutation in $P v P d h 1$. Indeed, $P v P d h 1$ is thought to modify the biochemical structure of lignin, rather than its total quantity or cell fate in the relevant pod structures. A loss of function mutation in this gene would therefore not lead to clear anatomical differences relative to the wild-type.

PvPdh1 as a candidate gene for the Pv03 QTL identified in this study. The strict conservation of the threonine at position 162 in $P v P d h 1$ highlights its functional importance. Of the 100 most similar known protein models, the one that lacks a threonine at this position is found in Trifolium subterraneum, a legume that produces pods that mature underground. PD is not relevant for seed dispersal in this species, and the gene may be undergoing pseudogenization. This threonine is maintained in the proteome of Selaginella moellendorffii, indicating that the residue has been conserved since before the lycophyte-euphyllophyte divergence. This coincides with the origin of lignin and lignans, and indicates the residue's functional role for members of the protein family. In a remarkable example of parallelism, independent loss of function mutations in this gene are found in certain domesticated populations in soybean (G. max) and in $P$. vulgaris, both species being subjected to selection for reduced dehiscence. This provides an additional example of strongly convergent phenotypic and molecular evolution (29). Similar examples of parallel evolution in common bean included the determinacy trait (fin or PvTFL1y; $(30,31))$ and absence of pigmentation $(P ;(32))$. 
Further research is needed to identify the biochemical and biophysical aspects responsible for differences in PD in domesticated dry beans. Notably, our results could shed light on the fundamental process of lignin synthesis. Dirigent-like genes, including $P v P d h 1$, encode non-enzymatic proteins that guide the dimerization of lignin and lignan monomers (33). The role of these proteins in lignin synthesis has been debated, with suggestions that polymerization is guided (34) or unguided (35). Varieties of common bean with mutations in Pdhl could be used to elucidate the role of this protein family in lignin synthesis generally.

QTLs and Candidate Genes Identified by Association Mapping. Association mapping revealed several other dehiscence-related QTLs across the gene pools and races of common bean (Table 1). Our ADP association mapping identified significant Pv03 SNPs in an interval that is syntenic with a region controlling dehiscence in cowpea (36). $N A C$ family and $\mathrm{C} 2 \mathrm{H} 2$-type zinc finger transcription factors are found in this region (Table 1), and members of these families affect PD in soybean (6) and rapeseed (37), respectively. Orthologs of these genes may also affect dehiscence in cowpea (36). Interestingly, the QTL is large enough to include $P v P d h 1$, although the QTLs discovered in Middle American beans and cowpeas are non-overlapping. Another major QTL for PD in Andean beans maps to Pv05, as described recently (18), and several genes in this region are candidates for future study. Rau et al. (18) noted that an ortholog of MYB26 exists in the qPD5.1-Pv region of interest on Pv05, which may be responsible for variation in PD. Significant Pv05 SNPs from our association mapping completely envelope the qPD5.1-Pv interval, supporting this result. Interestingly, our most significant Pv05 SNPs in the ADP are found just $22 \mathrm{~kb}$ from MYB46. MYB46 is involved in the same pathway as MYB26 and the soybean PD resistance gene $\operatorname{SHAT1-5}(38,6)$. MYB46 also works redundantly with $M Y B 83$, a gene that may play a role in cowpea pod development $(38,39)$, making $M Y B 46$ another potential subject of future study. synthase $A 7$ (CESA7, Table 1). CESA7 may play a role in fiber development in cowpea (39). 
253 Similarly, two polygalacturonases are found in this interval, and members of this family are

254 known to affect seed dispersal in A. thaliana (41). These genes may regulate dehiscence by 255 altering the breakdown of cell wall material in developing pods. Identifying polymorphisms in 256 PD candidate genes will be a promising area for future study.

Associations with environmental conditions. PD in common bean is correlated with environmental parameters. The PD-resistant allele of $P v P d h 1$ on Pv03 is found exclusively in genotypes with ancestry from race Durango (Table 1). Race Durango is adapted to higher elevations and lower humidity regions, particularly in the northern part of Mexico (13). The semi-arid conditions in these areas cause pods to become dry and brittle, which exacerbates PD. The non-functional $P v P d h 1$ allele rose to very high frequency in this ecogeographic race. In contrast, race Mesoamerica is adapted to humid lowlands, where environmental conditions mask PD and reduce selection pressure against it. In this race, the loss-of-function $P v P d h 1$ allele remains at low frequency and PD is widespread (Fig. 4A). Interestingly, this ecogeographic pattern closely parallels that of soybean, in which Pdhl-mediated resistance to PD is most common in arid regions (7). $P v P d h 1$ may also be responsible for the ease of threshing that has been noted in race Mesoamerica (13). In humid environments, the wild type $P v P d h 1$ allele may facilitate separation of seeds from pod material, while PD in the field remains low. In northern

271 Mexico, the semi-arid climate facilitates threshing but increases PD in the field. Under these

272 conditions, the PD-resistant allele is advantageous. Because of this trade-off, the polymorphism

273 in $P v P d h 1$ appears to be related to local adaptation (Fig. 5). Alleles that prevent PD will be

274 valuable in coming decades, which are predicted to be increasingly arid (42).

Redundancies in genetic control and maintenance of atavistic traits. Crosses between races

277 have tremendous potential for crop improvement (for example, between races Durango and

278 Mesoamerica (43)), but could also result in problematic gene complementation. Because several genes influence PD redundantly, cultivars descended from crosses between races could demonstrate atavistic transgressive segregation. This may be responsible for the high levels of dehiscence seen in some varieties of common bean. The interactions between these loci will also be of considerable importance for plant breeders. 


\section{Methods}

Details regarding materials and methods can be found in SI Methods. Pods were sectioned for microscopy using a Vibratome. Lignified and hydrophobic structures were visualized using epifluorescence microscopy after staining with Auramine $\mathrm{O}$.

The IxS population was genotyped using the Illumina Infinium II BARCBean6K_3 BeadChip. In Spring 2014, 238 RILs were grown in an unreplicated trial and visually phenotyped for the presence or absence of PD. In fall 2014, 191 RILs in a partially replicated trial were phenotyped based on proportion of pods dehiscing due to desiccation and force required to cause fracture. The maximum LOD score of 1000 random permutations of the data was used as a significance threshold.

Synteny mapping was conducted using LegumelP 2.0 (44) and CoGe SynMap (45). Candidate genes were identified by NCBI BLAST and clustered through the NCBI portal. Gene expression data were accessed through the Common Bean Gene Expression Atlas (22). PvPdh1 of ICA Bunsi, SXB 405, and RILs of interest was amplified by PCR and sequenced at the UC DNA Sequencing Facility. The COnstraint-Based multiple ALignment Tool (COBALT) (46) was used to align the PvPDH1 amino acid sequence to the most similar documented proteins of the NCBI database. PROVEAN (25) was used to estimate mutational effects.

PvPdh1 was sequenced in accessions with known pod shattering phenotypes from NPGS and UC Davis. Because members of the reproductively isolated Andean gene pool did not carry the T162N substitution, these individuals were filtered from subsequent analyses. For Middle American accessions, the categorical shattering scale used by USDA was translated into a simple numeric scale and PD between allele groups was compared using a student's t-test.

The ADP (27) consisted of 208 phenotyped accessions, and these were evaluated based on presence of $P D$ in the field, proportion dehiscing in the desiccator, and force required to cause fracture. The MDP (26) included 278 phenotyped varieties that were evaluated by the desiccation method alone. GWAS in both populations were conducted using TASSEL (47) through SNiPlay (48). Manhattan plots were visualized using the qqman R package (49).

Worldclim2 precipitation data (50) were compiled with Natural Earth national boundary shapefiles (51) in QGIS to visualize precipitation patterns in the range of Middle American beans.

ACKNOWLEDGEMENTS. The authors would like to thank S. Beebe (CIAT, Cali, Colombia) for providing seeds of the IXS population. Seeds of the ADP and MDP were generously provided 

Rezende, G. Coelho Portilho, N. Hamada, E. Yang, A. Herrera, J. Pimentel, M. Bustamante, E. White, J. Gonzales, and P. Augello contributed to DNA extractions, pod phenotyping, and other lab protocols. Paola Hurtado, Andrea Ariani, and other members of the Gepts lab provided ideas for data analysis. Funding for T.A.P. was provided through a Clif Bar Family Foundation Seed Matters fellowship and Lundberg Family Farms research support.

\section{References}

1. LPWG. (2017). A new subfamily classification of the Leguminosae based on a taxonomically comprehensive phylogeny The Legume Phylogeny Working Group (LPWG). Taxon, 66(1), 44-77.

2. Prakken R (1934). Inheritance of colours and pod characters in Phaseolus vulgaris L. Genetica, 16(3-4), 177-296.

3. Tiwari SP, Bhatia VS (1995). Characters of pod anatomy associated with resistance to podshattering in soybean. Ann Bot, 76(5), 483-485.

4. Dong Y, Wang YZ (2015). Seed shattering: from models to crops. Front Plant Sci, 6, 476.

5. Ballester $P$, Ferrandiz $C$ (2017). Shattering fruits: variations on a dehiscent theme. Curr Opin Plant Biol, 35, 68-75.

6. Dong Y, et al. (2014). Pod shattering resistance associated with domestication is mediated by a NAC gene in soybean. Nat Comm, 5, 3352.

7. Funatsuki $\mathrm{H}$, et al. (2014). Molecular basis of a shattering resistance boosting global dissemination of soybean. Proc Natl Acad Sci, 111(50), 17797-17802.

8. Suzuki M, Fujino K, Funatsuki H (2009). A major soybean QTL, qPDH1, controls pod dehiscence without marked morphological change. Plant Prod Sci, 12(2), 217-223.

9. Gepts, P et al. (2008). Genomics of Phaseolus beans, a major source of dietary protein and micronutrients in the tropics. Genomics of tropical crop plants eds. Moore PH, Ming R. (Springer, New York), 113-143.

10. Ariani A, Berny Mier y Teran JC, Gepts $P$ (2018). Spatial and temporal scales of range expansion in wild Phaseolus vulgaris. Mol Biol Evol, 35(1), 119-131.

11. Bitocchi E, et al. (2017). Beans (Phaseolus ssp.) as a model for understanding crop evolution. Front Plant Sci, 8, 722.

12. Harlan JR (1992). Crops and man (No. Ed. 2). (American Society of Agronomy, Madison, Wisconsin, USA).

13. Singh SP, Gepts P, Debouck DG (1991). Races of common bean (Phaseolus vulgaris, Fabaceae). Econ Bot, 45(3), 379-396.

14. Foster N, Cordell LS (Eds.). (1992). Chilies to chocolate: Food the Americas gave the world. University of Arizona Press.

15. Koinange EM, Singh SP, Gepts P. (1996). Genetic control of the domestication syndrome in common bean. Crop Sci, 36(4), 1037-1045.

16. Freyre R, et al. (1998). Towards an integrated linkage map of common bean. 4. Development of a core linkage map and alignment of RFLP maps. Theor App/ Genet, 97(5-6), 847-856.

17. Gioia T, Logozzo G, Kami J, Spagnoletti Zeuli P, Gepts P (2012). Identification and characterization of a homologue to the Arabidopsis INDEHISCENT gene in common bean. $J$ Hered, 104(2), 273-286. 
18. Rau D, et al. (2018). Genomic dissection of pod shattering in common bean: mutations at nonorthologous loci at the basis of convergent phenotypic evolution under domestication of leguminous species. The Plant Journal.

19. Gepts P, et al. (2005) Legumes as a model plant family. Genomics for food and feed Report of the Cross-Legume Advances through Genomics Conference. Plant Physiol, 137(4):1228-1235.

20. McClean PE, Mamidi S., McConnell M, Chikara S, Lee R (2010). Synteny mapping between common bean and soybean reveals extensive blocks of shared loci. BMC Genomics, 11(1), 184.

21. Schmutz J, et al. (2014). A reference genome for common bean and genome-wide analysis of dual domestications. Nature genetics, 46(7), 707.

22. O'Rourke JA et al. (2014). An RNA-Seq based gene expression atlas of the common bean. BMC Genomics, 15(1), 866.

23. Kim KW, et al. (2015). Trimeric structure of (+)-pinoresinol-forming dirigent protein at $1.95 \AA$ resolution with three isolated active sites. J Biol Chem, 290(3), 1308-1318.

24. Gasper R, et al. (2016). Dirigent protein mode of action revealed by the crystal structure of AtDIR6. Plant Physiol, pp-01281.

25. Choi Y, Chan AP (2015). PROVEAN web server: a tool to predict the functional effect of amino acid substitutions and indels. Bioinformatics 31(16): 2745-2747.

26. Moghaddam SM, et al. (2016). Genome-wide association study identifies candidate loci underlying agronomic traits in a Middle American diversity panel of common bean. Plant Genome, 9(3).

27. Cichy KA et al. (2015). A Phaseolus vulgaris diversity panel for Andean bean improvement. Crop Sci, 55(5), 2149-2160.

28. Murgia ML et al. (2017). A comprehensive phenotypic investigation of the "pod-shattering syndrome" in common bean. Front Plant Sci, 8, 251.

29. Lenser T, Theißen G (2013). Molecular mechanisms involved in convergent crop domestication. Trends in plant science, 18(12), 704-714.

30. Repinski SL, Kwak M, Gepts P (2012). The common bean growth habit gene PVTFL1y is a functional homolog of Arabidopsis TFL1. Theor Appl Genet, 124(8), 1539-1547.

31. Kwak M, Toro O, Debouck DG, Gepts, P. (2012). Multiple origins of the determinate growth habit in domesticated common bean (Phaseolus vulgaris). Ann Bot, 110(8), 1573-1580.

32. McClean PE, et al. (2018). White seed color in common bean (Phaseolus vulgaris) results from convergent evolution in the $P$ (Pigment) gene. New Phytol.

33. Davin LB, et al. (1997). Stereoselective bimolecular phenoxy radical coupling by an auxiliary (dirigent) protein without an active center. Science, 275(5298), 362-367.

34. Hosmani PS, et al. (2013). Dirigent domain-containing protein is part of the machinery required for formation of the lignin-based Casparian strip in the root. Proc Natl Acad Sci, 110(35), 1449814503.

35. Ralph J, et al. (2008). Lignification: are lignins biosynthesized via simple combinatorial chemistry or via proteinaceous control and template replication. Recent Advances in Polyphenol Research, eds. Daayf F, Lattanzio, V. (Blackwell, Chichester, UK), 36-66.

36. Lo, S et al. (2018). Identification of QTL controlling domestication-related traits in cowpea (Vigna unguiculata L. Walp). Sci Rep, 8(1), 6261.

37. Tao Z, et al. (2017). BnLATE, a Cys2/His2-type zinc-finger protein, enhances silique shattering resistance by negatively regulating lignin accumulation in the silique walls of Brassica napus. PloS one, 12(1), e0168046.

38. McCarthy RL, Zhong R, Ye ZH (2009). MYB83 is a direct target of SND1 and acts redundantly with MYB46 in the regulation of secondary cell wall biosynthesis in Arabidopsis. Plant Cell Physiol, 50(11), 1950-1964. 
39. Suanum W, et al. (2016). Co-localization of QTLs for pod fiber content and pod shattering in F2 and backcross populations between yardlong bean and wild cowpea. Mol Breed, 36(6), 80.

40. Tang $\mathrm{H}$ et al. (2013). Seed shattering in a wild sorghum is conferred by a locus unrelated to domestication. Proc Natl Acad Sci, 201305213.

41. Ogawa M, Kay P, Wilson S, Swain SM (2009). ARABIDOPSIS DEHISCENCE ZONE POLYGALACTURONASE1 (ADPG1), ADPG2, and QUARTET2 are polygalacturonases required for cell separation during reproductive development in Arabidopsis. Plant Cell, 21(1), 216-233.

42. Sherwood S, Fu Q (2014) A drier future? Science 343.6172, 737-739.

43. Singh SP, Molina A, Urrea CA, Gutiérrez JA (1993). Use of interracial hybridization in breeding the race Durango common bean. Canadian Journal Plant Science 73, 785-793.

44. Li J, Dai X, Zhuang Z, Zhao PX (2016). LegumelP 2.0—a platform for the study of gene function and genome evolution in legumes. Nucleic Acids Res, 44(D1), D1189-D1194.

45. Lyons E, Pedersen B, Kane J, Freeling M (2008). The value of nonmodel genomes and an example using SynMap within CoGe to dissect the hexaploidy that predates the rosids. Trop Plant Biol, 1(3-4), 181-190.

46. Papadopoulos JS, Agarwala R (2007). COBALT: constraint-based alignment tool for multiple protein sequences. Bioinformatics, 23(9), 1073-1079.

47. Bradbury PJ, et al. (2007). TASSEL: software for association mapping of complex traits in diverse samples. Bioinformatics, 23(19), 2633-2635.

48. Dereeper A, et al. (2011). SNiPlay: a web-based tool for detection, management and analysis of SNPs. Application to grapevine diversity projects. BMC Bioinformatics, 12(1), 134.

49. Turner SD (2018). qqman: an R package for visualizing GWAS results using $Q-Q$ and manhattan plots. J Open Source Softw, 3(25), 731.

50. Fick SE, Hijmans RJ (2017). WorldClim 2: new 1-km spatial resolution climate surfaces for global land areas. Intl J Climatol, 37(12), 4302-4315.

51. Kelso NV, Patterson T (2010). Introducing natural earth data-naturalearthdata.com. Geographia Technica, 5, 82-89.

52. Hagerty $\mathrm{CH}$, et al. (2016). Mapping snap bean pod and color traits, in a dry bean×snap bean recombinant inbred population. J Am Soc Hortic Sci, 141(2), 131-138.

53. Liljegren SJ, et al. (2004). Control of fruit patterning in Arabidopsis by INDEHISCENT. Cell 116, 843-853. 

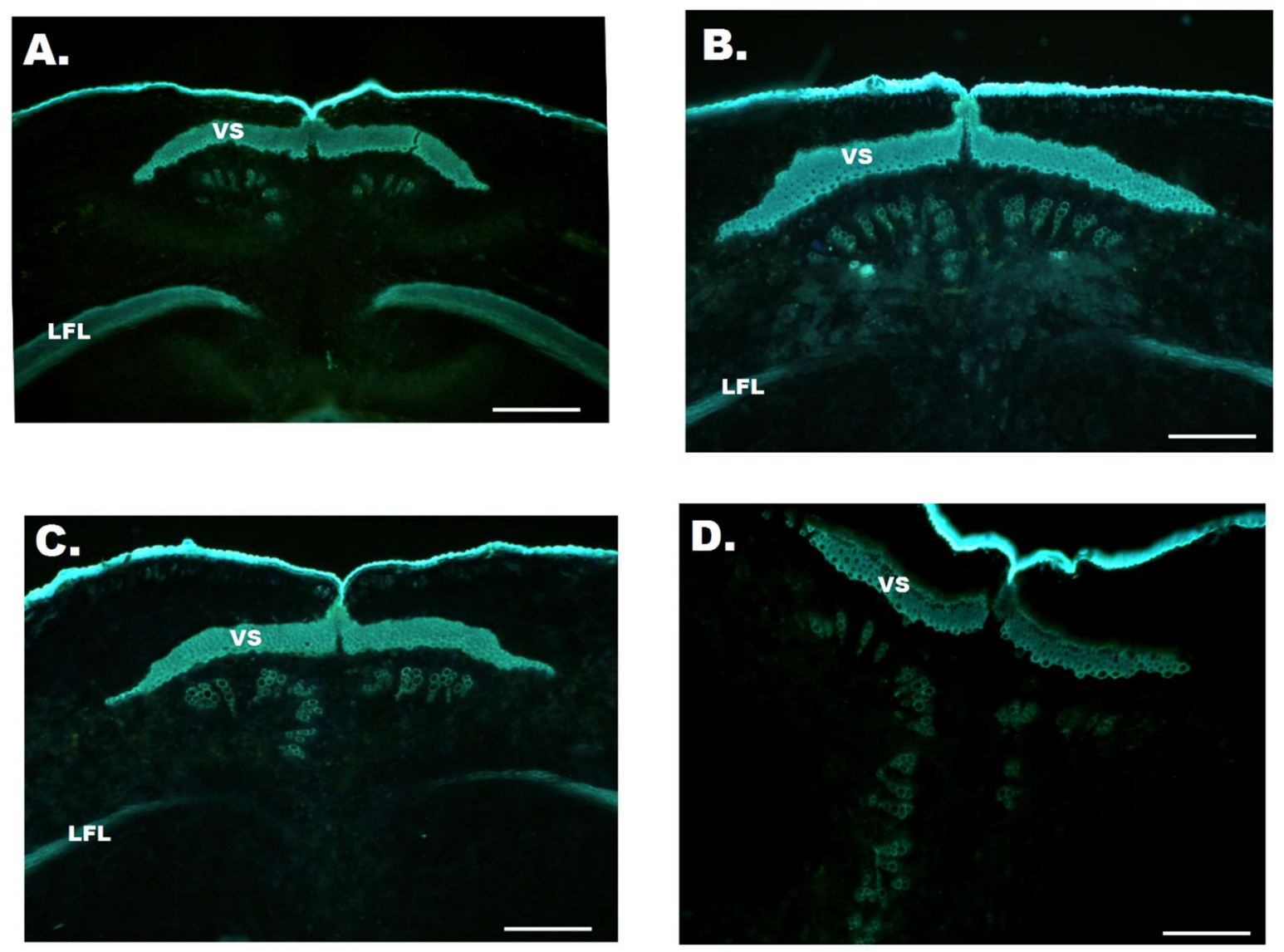

443

444

445

446

447

448

449

450

451

452

453
Fig. 1. Variation in PD-related structures in common bean. (A) Cross-section of the ventral suture of $\mathrm{G} 12873$, a wild Middle American bean. Wild beans show very high pod dehiscence (PD) and extensive lignified vascular sheath (VS) and fiber layer (LFL) deposition in pod walls. (B) In PD-susceptible domesticated dry beans (cv. ICA Bunsi shown), LFL deposition is reduced relative to wild types, indicating that these cells may be related to Middle American common bean domestication. (C) PD-resistant dry beans (cv. SXB 405 shown) are anatomically similar to PD-susceptible domesticated types (see B). (D) Stringless varieties (cv. Midas shown) display a reduction in VS lignification, including a reduction in secondary cell wall thickening. The LFL is absent in these varieties. Scale bars represent $100 \mu \mathrm{m}$. 

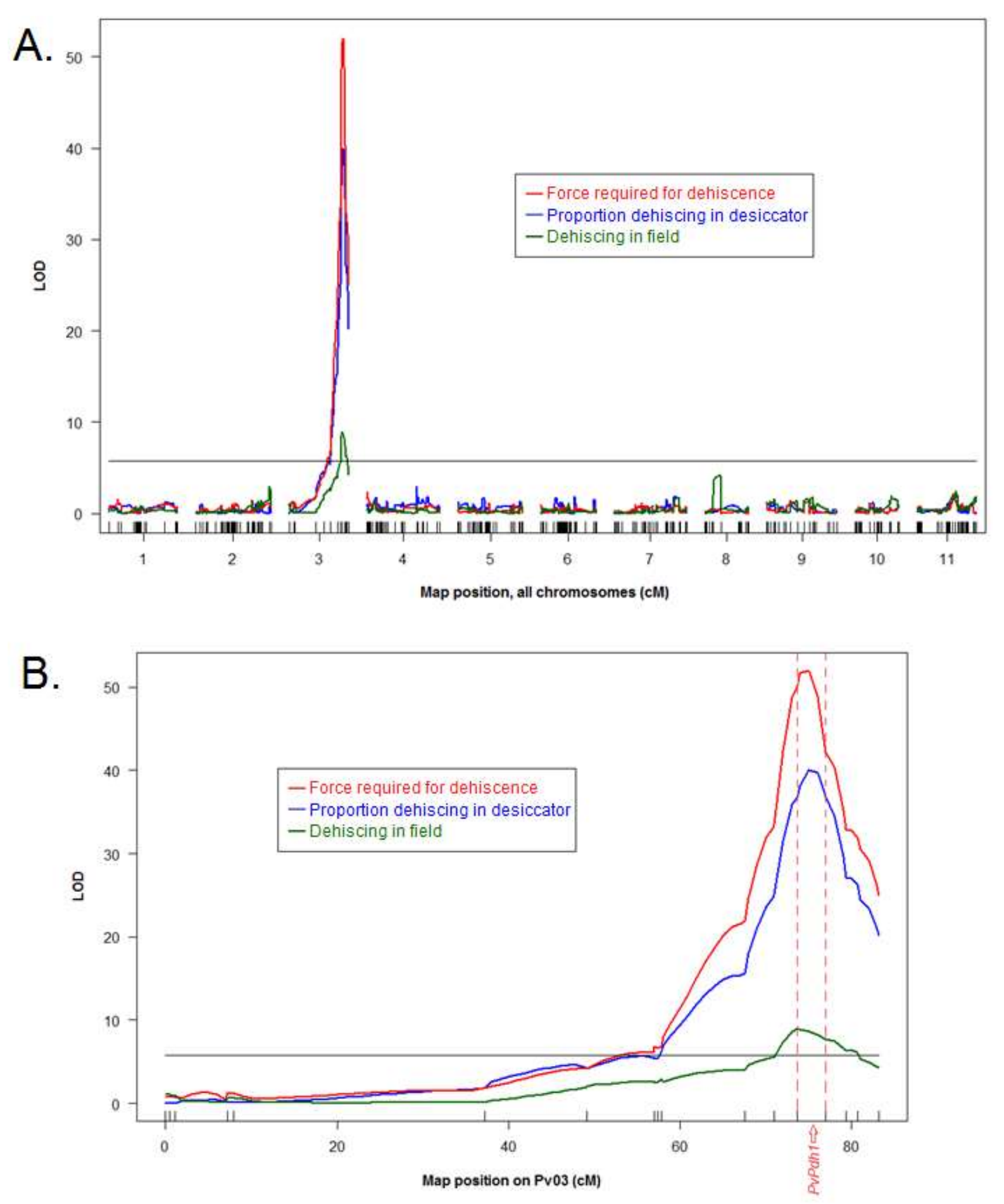

Fig. 2. Pod dehiscence (PD) QTL mapping based on three phenotyping methods. (A) Genomewide and (B) Pv03-specific mapping results. All methods produced statistically significant results in the same region of chromosome Pv03. The significance threshold, determined by 1000 randomized permutations of the data, is shown as a black bar at LOD=5.80. The common bean ortholog of $P d h 1$, which regulates PD in soybean, is located between the most significant markers from QTL mapping (Table S1). 

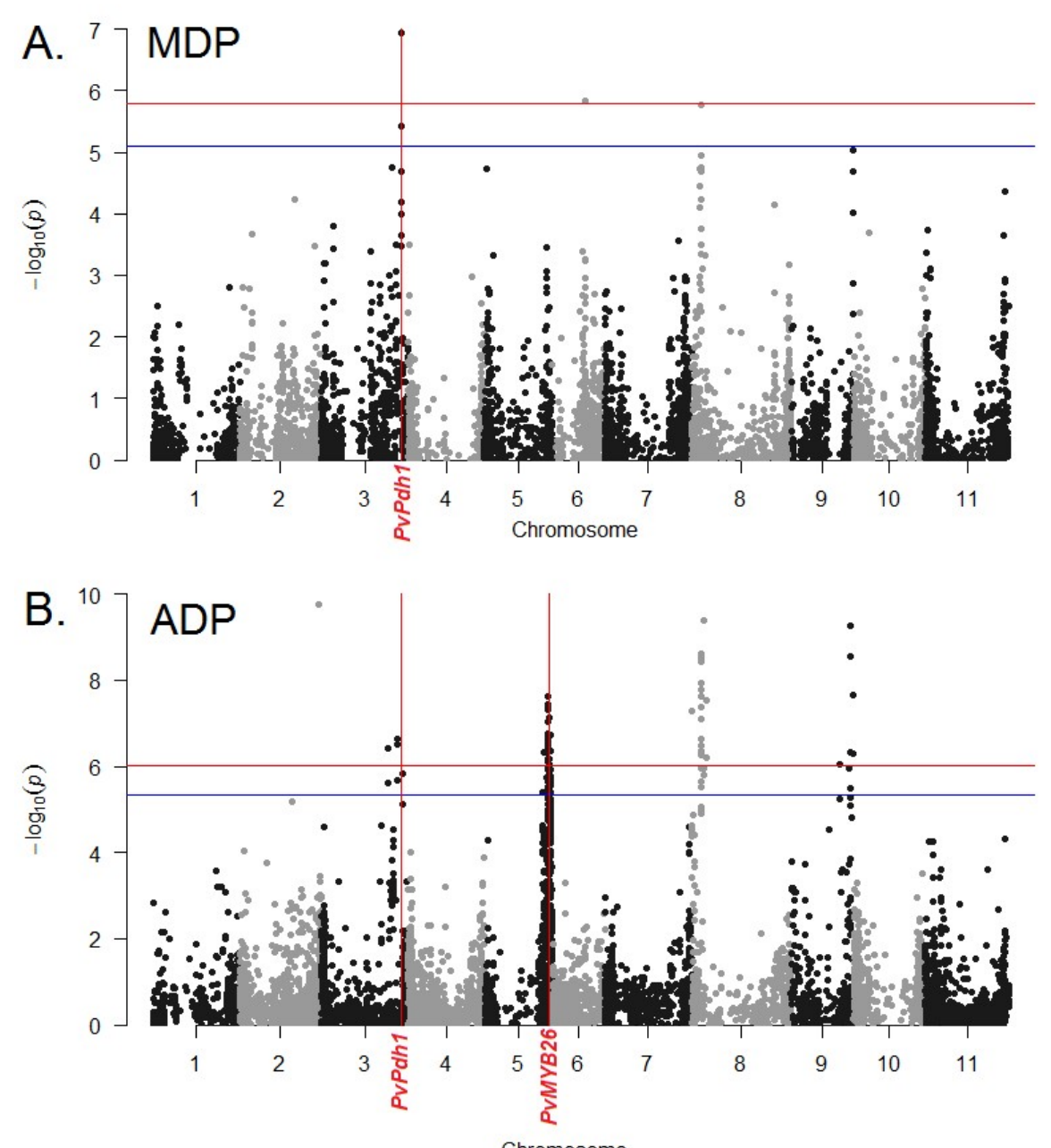

Chromosome

Fig. 3. GWAS of PD in independently domesticated common bean populations. (A) In the Middle American Diversity Panel (MDP), the most significant SNP is located $5.7 \mathrm{kbp}$ from the PvPdh1 putative causal polymorphism. Pv06 and Pv08 also included loci of interest. (B) In the Andean Diversity Panel (ADP), chromosomes Pv03, Pv05, Pv08, and Pv09 include major regions of interest. SNPs located near PvMYB26 (18) on Pv05 were highly significant. Horizontal red and blue lines indicate the Bonferroni-corrected significance threshold for an alpha of 0.01 and 0.05 , respectively. Based on the proportion of pods dehiscing in a desiccator, with correction for population structure by PCA. 

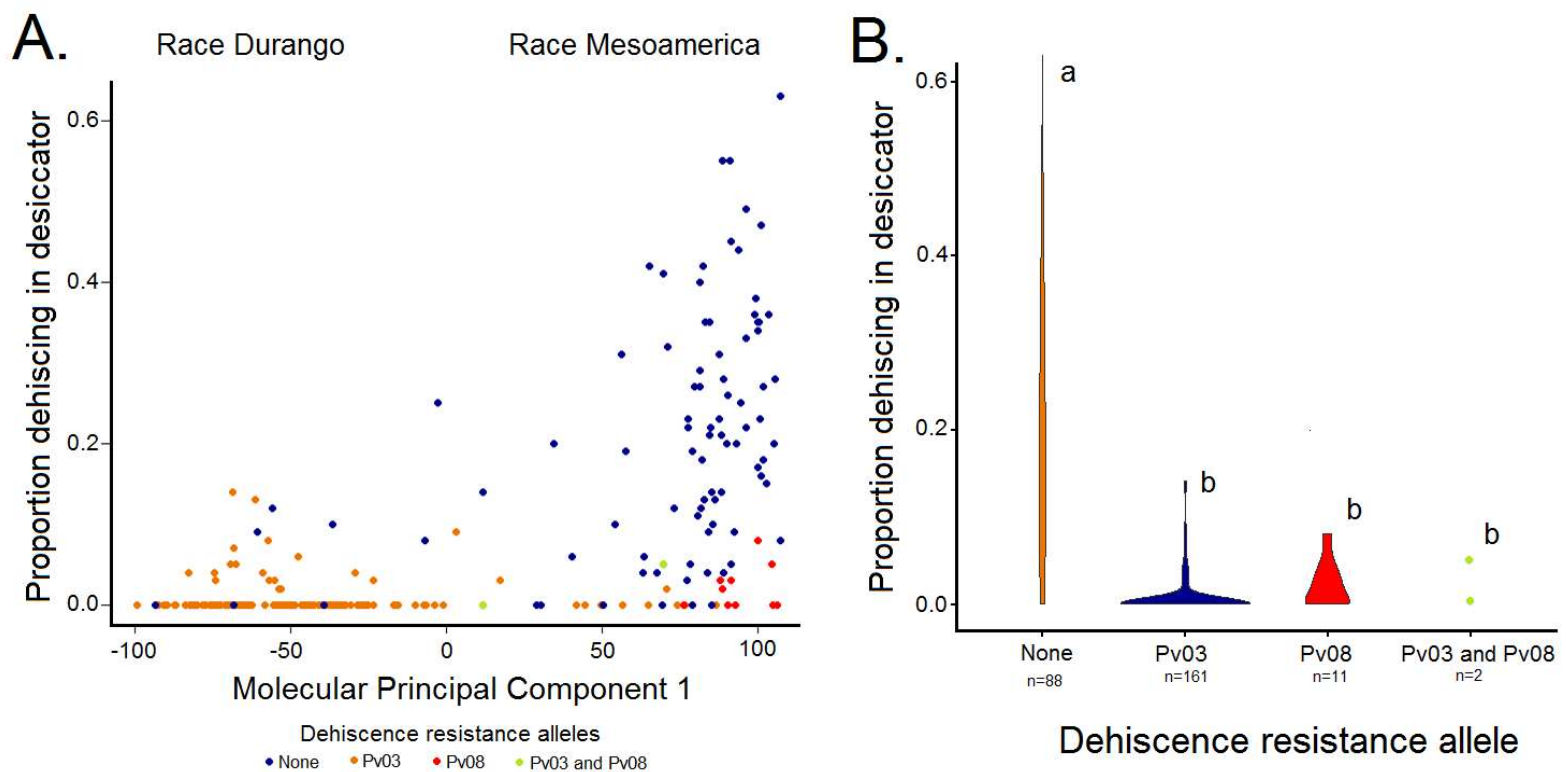

Fig. 4. The relationship between $P D$, ecogeographic race, and resistance alleles. (A)

478 The first principal component of genetic data for the MDP separates race Durango (at left) from race Mesoamerica (at right). Members of race Durango have low susceptibility to PD relative to members of race Mesoamerica. Accessions are color coded by genotype at the GWAS peaks on Pv03 and Pv08. (B) A violin plot showing of the extent of PD by allele in the MDP. Accessions with these PD resistance loci have significantly lower levels of PD than accessions with neither allele. Letters "a" and "b" distinguish significantly different groups (Tukey HSD). 


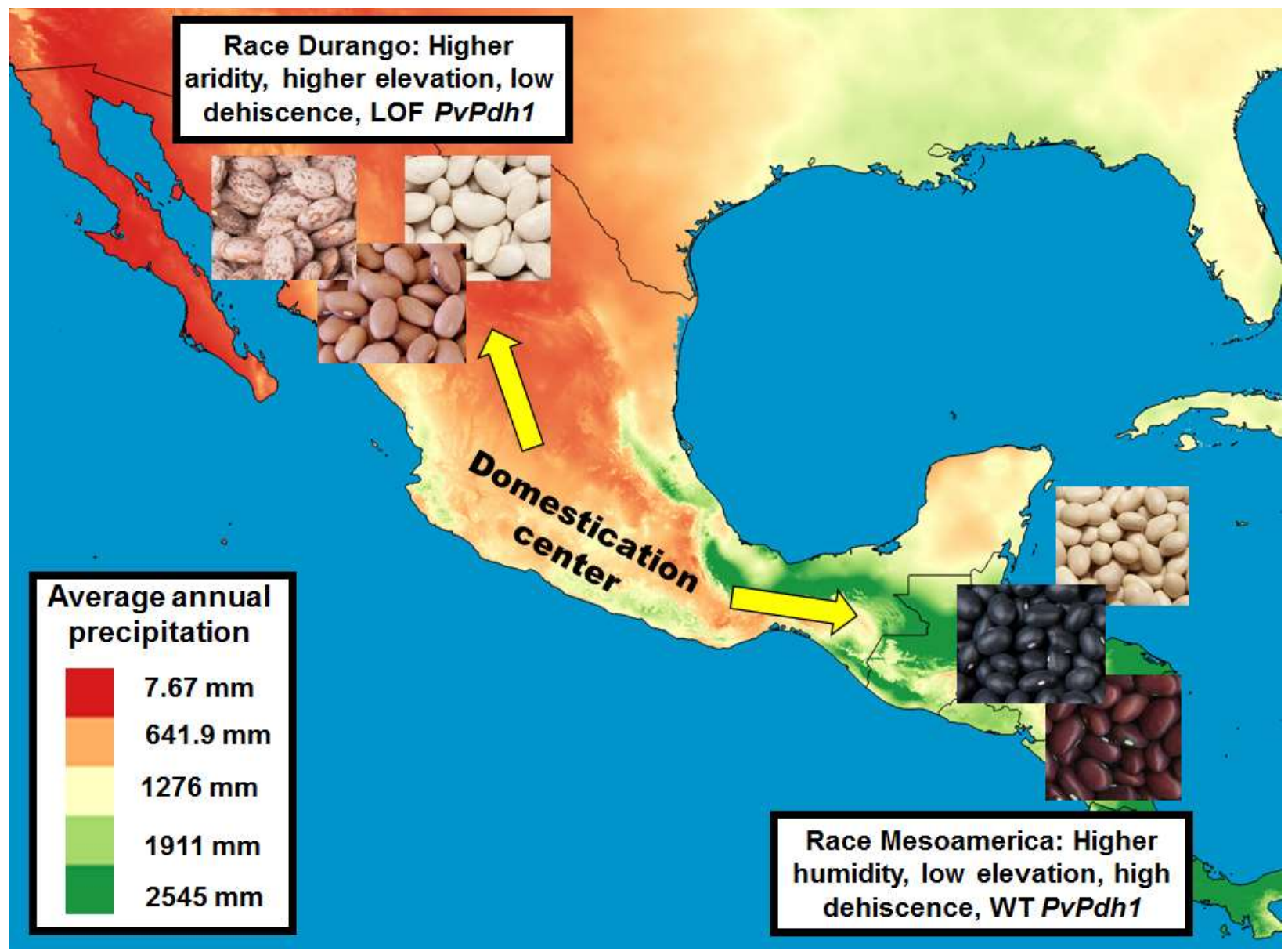

Fig. 5. PvPdh1 is related to local adaptation and range expansion in common bean. PD is nearly absent in Race Durango, a group adapted to the hot, dry environments of northern Mexico, where environmental aridity exacerbates PD. The loss of function $P v P d h 1$ allele is nearly at fixation in this population. In contrast, race Mesoamerica is adapted to humid lowlands, where conditions mask PD susceptibility. PD has been selected against less strongly in this population, and the wild type PvPdh1 predominates. For detailed information on the geographic distribution of these races, see Singh et al. (13). 
Table 1. Summary of pod fiber or dehiscence QTLs, their genome locations, potential candidate genes, and homologies with other species

\begin{tabular}{|c|c|c|c|c|c|c|}
\hline $\begin{array}{l}\text { Chromosome } \\
\text { or Linkage } \\
\text { Group }\end{array}$ & $\begin{array}{l}\text { Gene } \\
\text { pool }\end{array}$ & $\begin{array}{l}\text { Ecogeographic } \\
\text { race, from 13; } \\
\text { if available) }\end{array}$ & $\begin{array}{l}\text { QTL } \\
\text { location (bp, } \\
\text { v1.0, from 8) }\end{array}$ & $\begin{array}{l}\text { Potential candidate } \\
\text { genes (when } \\
\text { identified) }\end{array}$ & $\begin{array}{l}\text { Source in } \\
\text { Phaseolus } \\
\text { vulgaris }\end{array}$ & $\begin{array}{l}\text { Homologies in other species (when } \\
\text { known) }\end{array}$ \\
\hline Pv02 & Andean & $\begin{array}{l}\text { Nueva } \\
\text { Granada }\end{array}$ & $\begin{array}{l}43,425,893- \\
43,900,872\end{array}$ & PVIND & $(15,52)$ & Arabidopsis: (53) \\
\hline Pv03 & $\begin{array}{l}\text { Middle } \\
\text { American }\end{array}$ & Durango & $\begin{array}{l}47,527,006- \\
48,475,205\end{array}$ & $\begin{array}{l}\text { PvPdh1: dirigent } \\
\text { family }\end{array}$ & $\begin{array}{l}\text { This } \\
\text { research }\end{array}$ & Soybean: (7) \\
\hline Pv03 & Andean & & $\begin{array}{l}39,768,300- \\
48,451,789\end{array}$ & $\begin{array}{l}\text { NAC family, } \mathrm{C} 2 \mathrm{H} 2 \\
\text { zinc finger }\end{array}$ & $\begin{array}{l}\text { This } \\
\text { research }\end{array}$ & Cowpea: (36) \\
\hline Pv04 & $\begin{array}{l}\text { Middle } \\
\text { American }\end{array}$ & & $42,310,662$ & & $(52)$ & \\
\hline Pv05 & Andean & $\begin{array}{l}\text { Nueva } \\
\text { Granada }\end{array}$ & $\begin{array}{l}35,000,893- \\
39,497,309\end{array}$ & MYB26, MYB46 & $\begin{array}{l}(18) \text {; this } \\
\text { research }\end{array}$ & Cowpea: $(36,39)$; Arabidopsis: (38) \\
\hline Pv08 & $\begin{array}{l}\text { Andean } \\
\text { \& Middle } \\
\text { American }\end{array}$ & Mesoamerica & $\begin{array}{l}330,345- \\
9,215,942\end{array}$ & $\begin{array}{l}\text { MYB family, WRKY } \\
\text { family, } \\
\text { polygalacturonase }\end{array}$ & $\begin{array}{l}\text { This } \\
\text { research }\end{array}$ & Sorghum: (40); Arabidopsis: (41) \\
\hline Pv09 & Andean & & $\begin{array}{l}29,587,741- \\
37,450,759\end{array}$ & $\begin{array}{l}\text { CESA7, } \\
\text { polygalacturonases }\end{array}$ & $\begin{array}{l}\text { This } \\
\text { research }\end{array}$ & Cowpea: (39) \\
\hline
\end{tabular}




\title{
Supporting Information
}

\section{Genetic control of reduced pod dehiscence in domesticated common bean: Associations with range expansion and local aridity conditions}

\author{
Travis A. Parker, Jorge C. Berny Mier y Teran, Antonia Palkovic, Judy Jernstedt, and \\ Paul Gepts
}

\section{SI Methods}

Microscopy. Pods of G12873 (wild, high dehiscence), ICA Bunsi (domesticated dry bean, dehiscence susceptible) SXB 405 (domesticated dry bean, dehiscence resistant), and Midas (domesticated snap bean, dehiscence susceptible) were Vibratome-sectioned to identify morphological differences that might be associated with PD. All sectioned pods were greenhouse-grown and harvested when pods were at full size with seeds filled, at the onset of pod color change. All sections were 100 micrometers thick and made in a transverse plane perpendicular to the fibers of interest. All sections were treated with Auramine $O$ for at least 20 minutes. Fluorescence was visualized using an Olympus microscope.

RI population and phenotyping for pod dehiscence. A recombinant inbred (RI) population developed from a cross between ICA Bunsi (domesticated, PD-susceptible) and SXB 405 (domesticated, PD-resistant) was used for QTL mapping (1). The population (IxS) of 238 RILs was field-grown during the spring and summer of 2014. The spring planting was an unreplicated trial conducted in Coachella, California. At maturity, plots were visually evaluated for the presence or absence of PD, and the data were used as a phenotype for QTL mapping. During the summer of 2014 , the RI population was grown in a replicated trial in Davis, California. At maturity, dried pods from 191 RILs were harvested from each plot; these were evaluated for susceptibility to PD by two methods. First, all pods were desiccated at $65^{\circ} \mathrm{C}$ for seven days, and then returned to room temperature for a minimum of seven additional days. The proportion of pods dehiscence in this process was recorded for each plot. Second, the amount of force required to induce pod fracture was measured using an Imada force measurement gauge (method modified from (2)). A bit mounted to the gauge was used to press the ventral side of each pod at the most apical seed, and the peak force required to cause fracture at the apical end of the pod beak was recorded. Force required for PD was normalized to account for small but significant differences between note-takers, and the standardized score was used for QTL mapping.

Genotyping. Genomic DNA was extracted from parents and RILs of the IxS population using a modified CTAB protocol. DNA quality was confirmed using a NanoDrop spectrophotometer. The IxS population was genotyped using the Illumina Infinium II BARCBean6K_3 BeadChip (3); 382 segregating SNPs were identified in the population. Primers spanning the transcribed sequence of Phvul.003G252100, a candidate gene underlying the major QTL identified in this study, were developed using the NCBI Primer-BLAST tool. Differences in the genomic sequence around 
PvPDH1 exist between the Middle American and Andean gene pools, so variable PCR primers were used between the gene pools. PvPdh1ALL MA Forward (CATCTCCCCCATTTTCCCCC) and PvPdh1ALL Reverse (AACACGTGGAAGAGGAGGATT) were used for Middle American accessions, while PvPdh1ALL Andean Forward (CATCTCTCCCATTTTCTCCT) and PvPdh1ALL Reverse (AACACGTGGAAGAGGAGGATT) were used for Andean types. PCR conditions for this amplification included an initial denaturation at $95^{\circ} \mathrm{C}$ for $180 \mathrm{~s}, 38$ cycles of $95^{\circ} \mathrm{C}$ for $30 \mathrm{~s}, 51^{\circ} \mathrm{C}$ for $30 \mathrm{~s}$, and $68^{\circ} \mathrm{C}$ for $60 \mathrm{~s}$, and a final elongation step of $68^{\circ} \mathrm{C}$ for $300 \mathrm{~s}$. PCR products were cleaned using a GeneJET PCR Purification Kit and sequenced at the UC DNA Sequencing Facility by Sanger sequencing.

QTL mapping. Composite interval mapping was conducted using the R package R/qtl (4). Field dehiscence, proportion dehiscing in a desiccator, and force measurements were separately used to identify PD QTLs marked by SNPs. The maximum LOD score of 1000 randomized permutations of the data was used as a significance threshold. Multiple QTL mapping was conducted using the scantwo function in R/qtl and by running the analysis with RILs subsetted by genotype at the most significant marker near PvPdh1 on Pv03.

Synteny mapping and expression. Candidate genes related to PD were identified in Phytozome 12 (5). Synteny comparisons between common bean and soybean were made using the Legume Information System 2.0 (6); these were verified using available literature (7, 8). The CoGe SynMap (9) and LegumelP 2.0 (6) synteny tools were used to compare syntenic regions between Arabidopsis (Col-0, TAIR10), common bean (G19833, Pvulgaris_V1.0_218; (8)), and soybean (Williams 82, Release 1.1; (10)). For tree generation, the PvPDH1 amino acid sequence was BLASTed against the A. thaliana, G. max, and $P$. vulgaris proteomes. Default Grishin settings were used to construct the distance matrix. A fast-minimum evolution tree (11) was generated based on a maximum sequence difference of 0.85 . Gene expression from a variety of tissues and developmental stages were based on published data (12) and visualized in $\mathrm{R}$.

Amino acid conservation analyses. The complete amino acid sequence of $P v P d h 1$ from accession G19833 was BLASTed against the $\mathrm{NCBI}$ proteome database. The COnstraint-Based multiple ALignment Tool (COBALT) (13) was used to align the most similar proteins known among several plant taxa and identify conserved residues. The Protein Variation Effect Analyzer (PROVEAN) software tool (14) was used to estimate the effect of mutations of interest.

Validation of the role of PvPdh1 in a wider population. The Genetic Resources Information Network (GRIN) database of the National Plant Germplasm (NPGS) includes PD phenotype data for the genus Phaseolus. PD-susceptible and PD-resistant varieties from this pool were selected for validation of the role of PvPdh1 in PD. A small number of varieties commonly grown at UC Davis with known PD phenotypes were also genotyped. Stringless snap bean varieties were specifically excluded from the analysis to avoid the epistatic effect of the Stringless (St) locus on PD. Genomic DNA was extracted using a modified CTAB method; amplification and Sanger sequencing of $P v P d h 1$ were conducted as described previously. Genotypes were separated into the Andean or Middle American gene pool based on an indel in the 3' UTR of 
$584 \quad$ PvPdh1. This indel consistently predicted the gene pool in varieties of known ancestry. After 585 sequencing, Middle American varieties were divided into groups based on amino acid at position 162 of $P v P d h 1$. The degree of dehiscence between these groups was evaluated by 587 student's t-test.

Validation of QTL mapping results using association mapping.

590 Two hundred and eight accessions of the Andean Diversity Panel (ADP) (15) were grown in 591 Davis, CA during summer 2016. PD in the field, proportion dehiscing in a desiccator, and force 592 required for fracture were recorded. Principal component analysis was conducted on SNP data 593 for the population, and the results were used as covariates to account for population structure. 594 Two hundred seventy-eight members of the BeanCAP Middle American Diversity Panel (MDP) 595 (16) were phenotyped for PD by desiccation in 2017. Association mapping was conducted using 596 GLM in TASSEL (17) via SNiPlay (18). All results were visualized using the qqman R package 597 (19).

Precipitation map generation. Precipitation across the native range of Middle American beans was mapped in QGIS 2.18.19 using data from worldclim2 (20). National boundaries and coastlines were added using shapefiles available through Natural Earth (21). USGS

602 topographical global raster data grids were also used to improve the visualization of coastlines 603 (https://topotools.cr.usgs.gov/gmted viewer/gmted2010 global grids.php). 


\section{Supporting Information}

605

606

607

608

\section{Supplemental Figures}
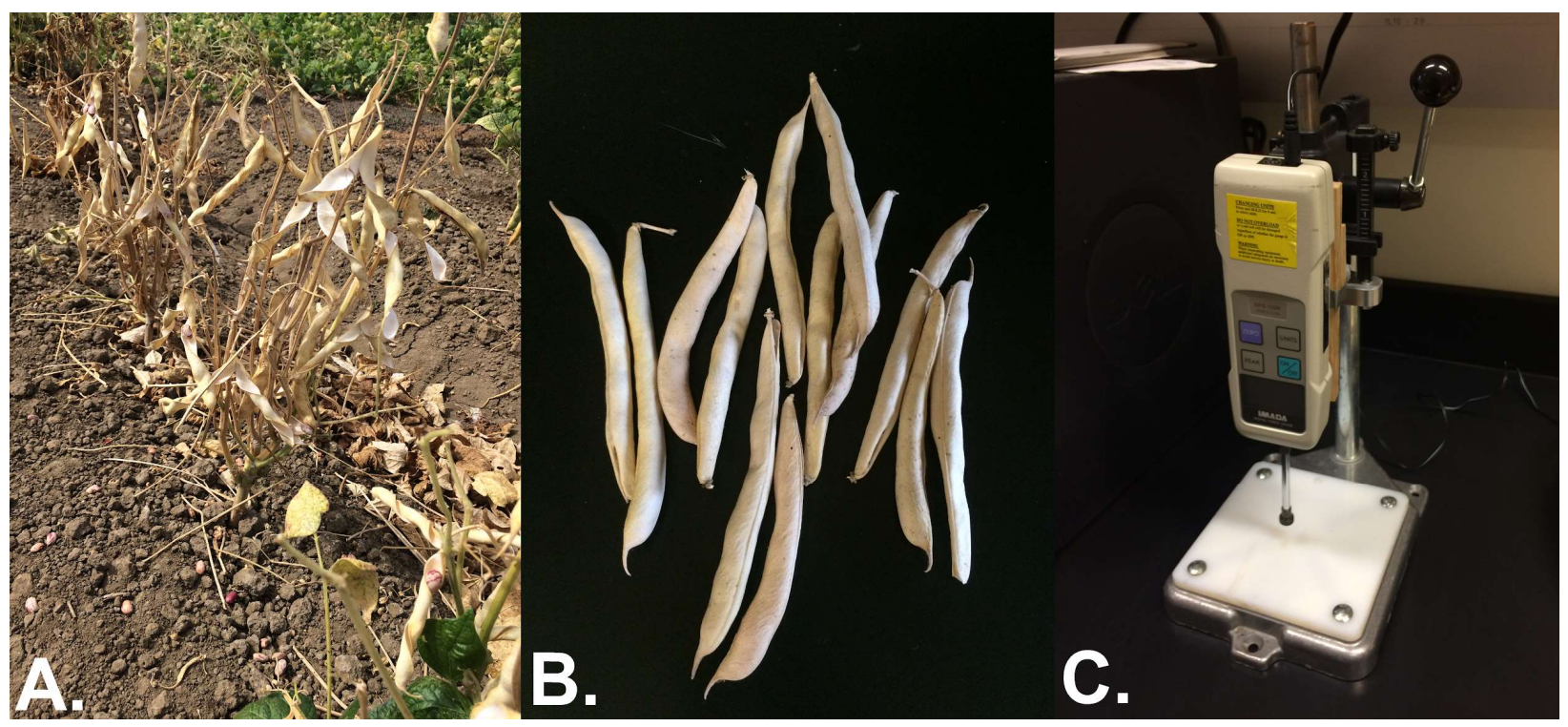

Fig. S1. Phenotyping methods. PD was evaluated by (A) visual inspection of PD in the field, (B) proportion of dehiscing pods in a desiccator (none dehiscing in this sample), and (C) force required to induce fracture with a force measurement gauge. 

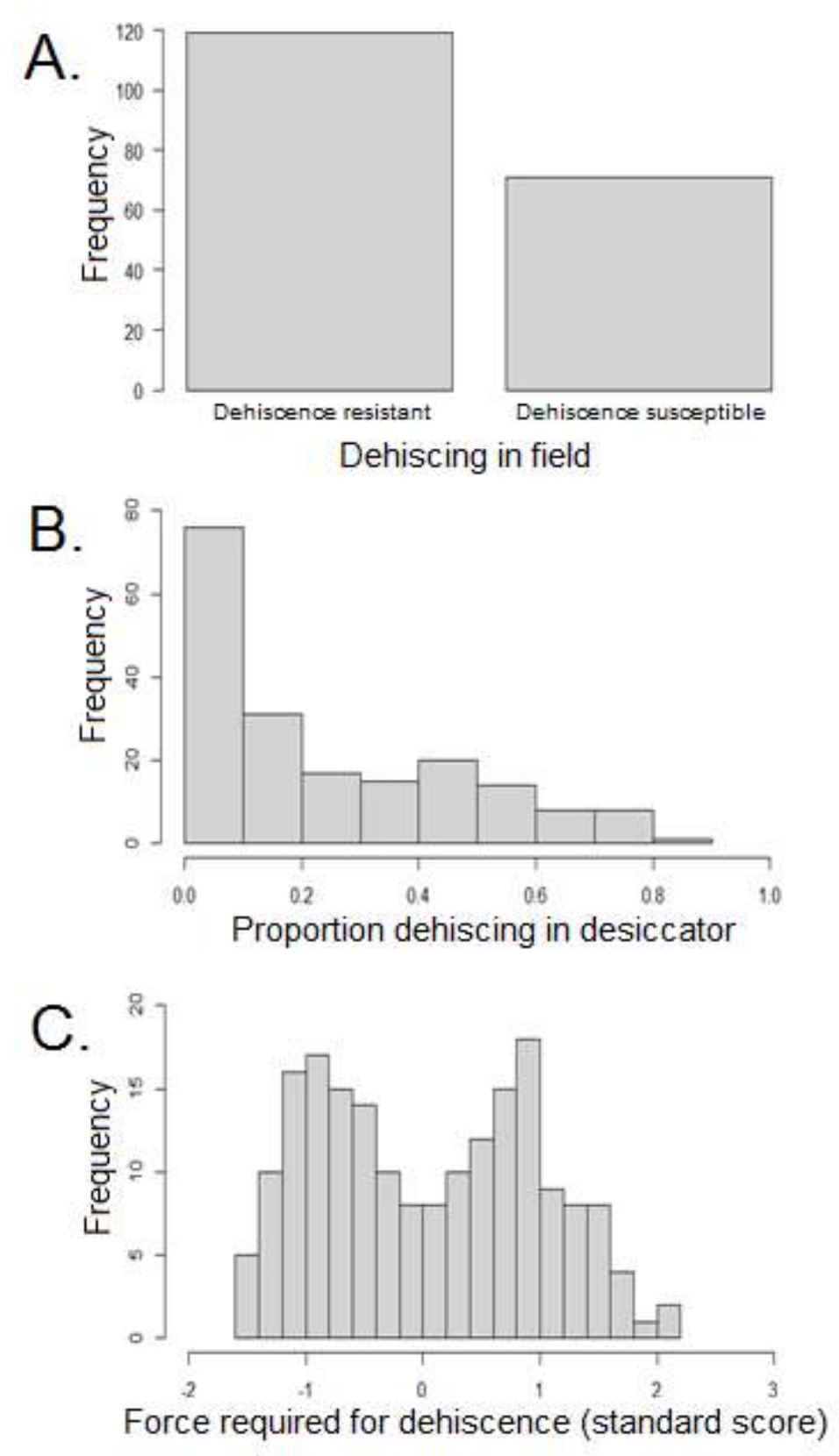

Fig. S2. Phenotyping distributions in the ICA Bunsi/SXB 405 RI population. (A) 

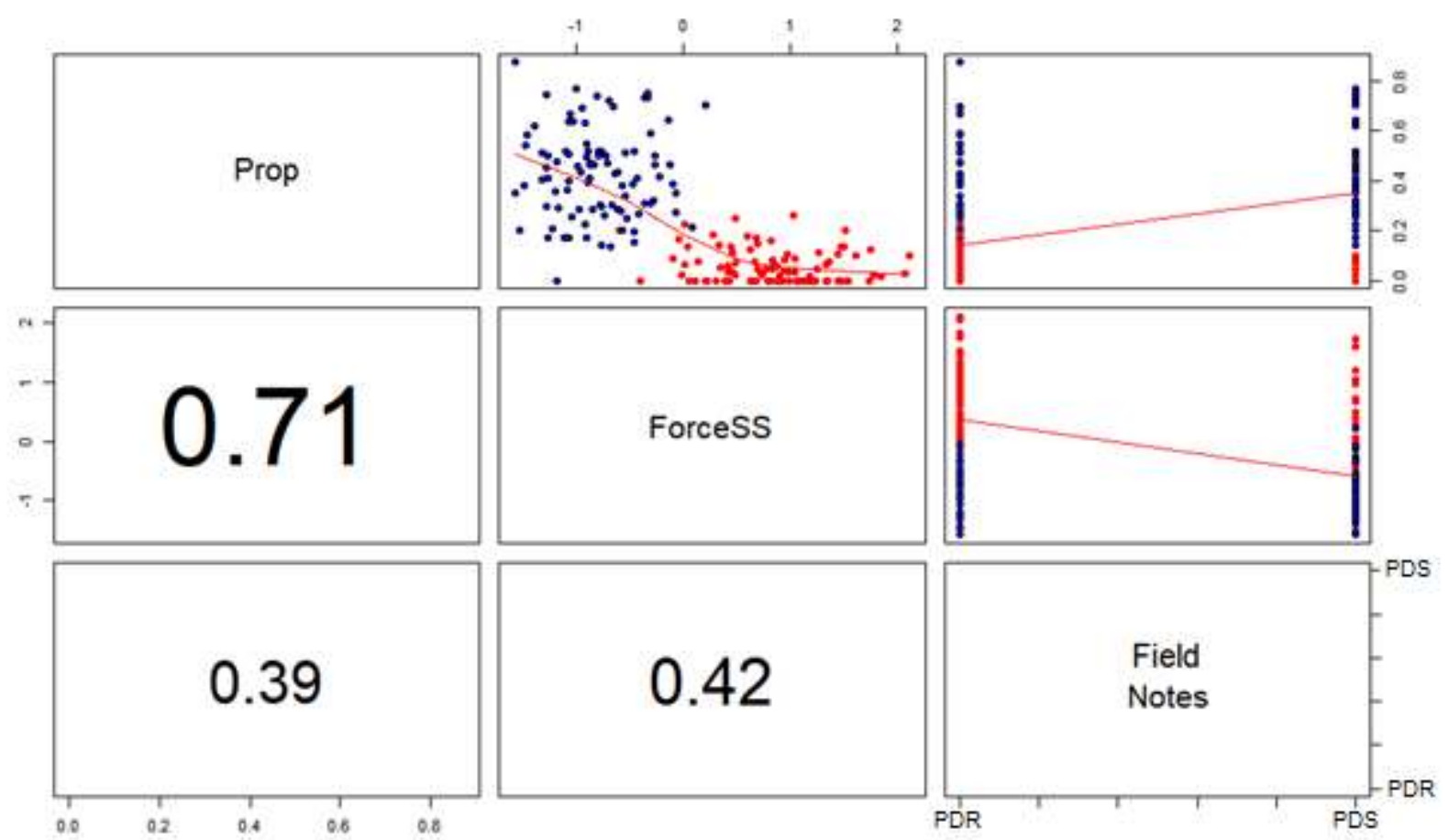

Fig. S3. Correlations between phenotyping methods in the IXS RI population. RI lines are color coded by genotype at the PvPdh1 locus. The numbers in the lower left panels indicate the correlation coefficients between those methods. PDS=PD susceptible, PDR=PD resistant. 
624

Fig. S4. A rooted neighbor joining tree based on sequence of GmPDH1, PHAVU_003G252100g, and the most similar dirigent proteins of $G$. max and $P$. vulgaris in the NCBI database. GmPDH1 and PHAVU_003G252100g form a clade among all the proteins of

AB826447.1 Toyomusume PDH1 [Glycine max] GmPDH1

OXP_007156024.1 hypothetical protein PHAVU_003G252100g [Phaseolus vulgaris]PvPDH1 $-{ }_{-}^{-X} \_007160128.1$ hypothetical protein PHAVU_002G294900g, partial [Phaseolus vulgaris]

OXP_014634029.1 disease resistance response protein 206 [Glycine max]

ACU15842.1 unknown [Glycine max]

oXP_007160127.1 hypothetical protein PHAVU_002G294800g [Phaseolus vulgaris]

LOXP_003525358.1 disease resistance response protein 206-like [Glycine max]

KRH41265.1 hypothetical protein GLYMA_08G019900 [Glycine max]

NP 001238065.2 dirigent-like protein precursor [Glycine max] these species, supporting their orthology. Tree derived from a Grishin protein distance matrix and rooted using 12 distantly related dirigent-like proteins. 


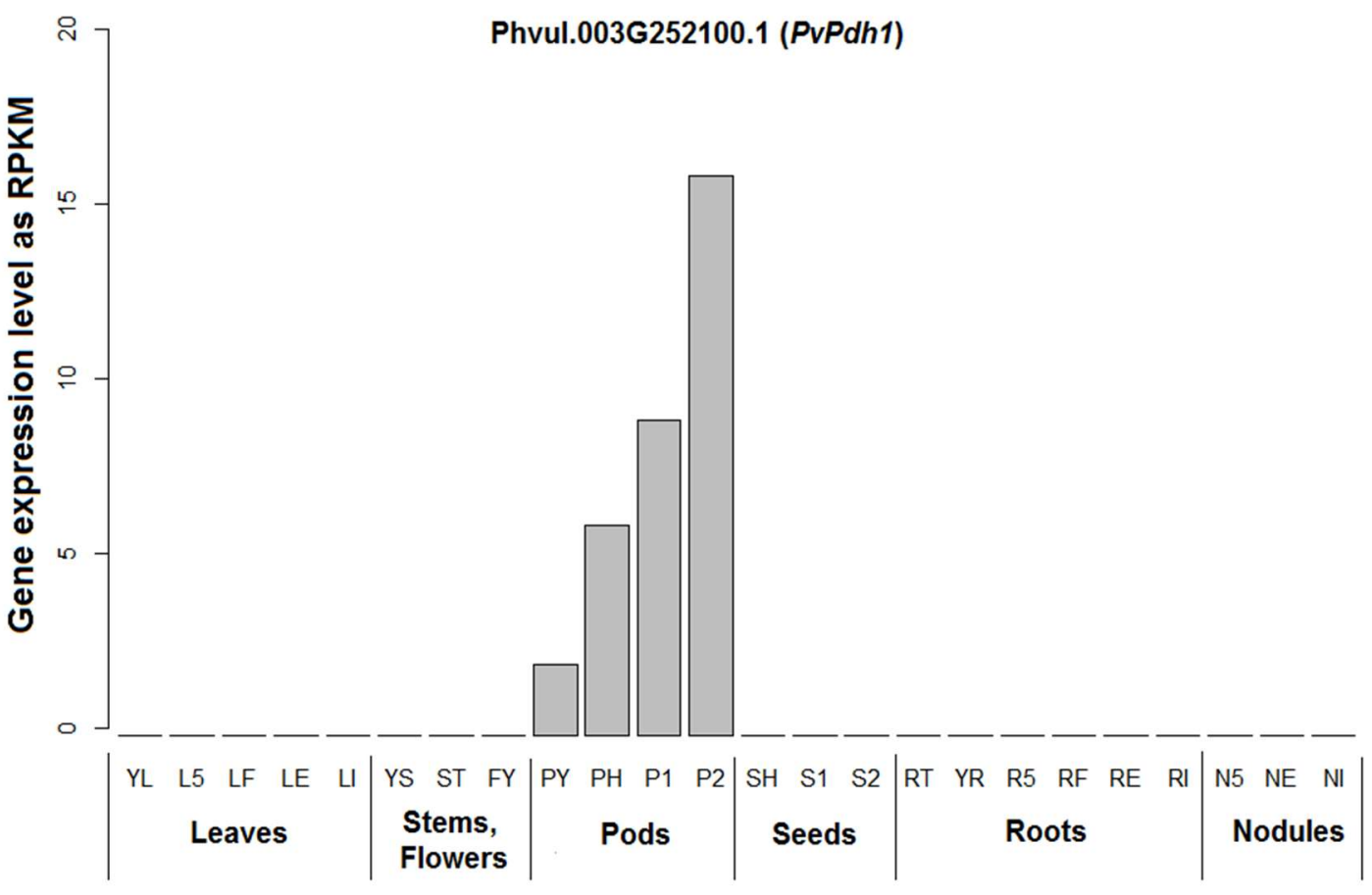

633

634

635

636

637

638

639

640

641

642

643

644

645

646

647

648

649

650

651

652

653

654

655

656

657

Fig. S5. Expression of Phvul.003G252100.1 (PvPdh1) is unique to pods in P. vulgaris cv. Negro Jamapa. This pattern is extremely unusual even among homologs of Arabidopsis genes affecting PD. YL- Fully expanded 2nd trifoliate leaf tissue from fertilized plants L5- Leaf tissue collected 5 days after plants were inoculated with effective rhizobium; LF- Leaf tissue from fertilized plants collected at the same time of LE and LI; LE- Leaf tissue collected 21 days after plants were inoculated with effective rhizobium LI- Leaf tissue collected 21 days after plants were inoculated with ineffective rhizobium; YS- All stem internodes above the cotyledon collected at the 2nd trifoliate stage; ST- Shoot tip, including the apical meristem, collected at the 2nd trifoliate stage; FY- Young flowers, collected prior to floral emergence; PY- Young pods, collected 1 to 4 days after floral senescence. Samples contain developing embryos at globular stage PH- Pods approximately 9cm long, associated with seeds at heart stage (pod only); P1Pods between 10 and $11 \mathrm{~cm}$ long, associated with stage 1 seeds (pod only); P2- Pods between 12 and $13 \mathrm{~cm}$ long associated with stage 2 seeds (pod only); $\mathrm{SH}$ - Heart stage seeds, between 3 and $4 \mathrm{~mm}$ across and approximately $7 \mathrm{mg} \mathrm{S1}$ - Stage 1 seeds, between 6 and $7 \mathrm{~mm}$ across and approximately $50 \mathrm{mg}$; S2- Stage 2 seeds, between 8 and $10 \mathrm{~mm}$ across and between 140 and $150 \mathrm{mg}$; RT- Root tips, $0.5 \mathrm{~cm}$ of tissue, collected from fertilized plants at 2nd trifoliate stage of development; YR-Whole roots, including root tips, collected at the 2nd trifoliate stage of development; R5- Whole roots separated from 5 day old pre-fixing nodules; RF- Whole roots from fertilized plants collected at the same time as RE and RI; RE- Whole roots separated from fix+ nodules collected 21 days after inoculation; RI- Whole roots separated from fix- nodules collected 21 days after inoculation; N5- Pre-fixing (effective) nodules collected 5 days after inoculation ;NE- Effectively fixing nodules collected 21 days after inoculation; NI- Ineffectively fixing nodules collected 21 days after inoculation. From O'Rourke et al. (12). 


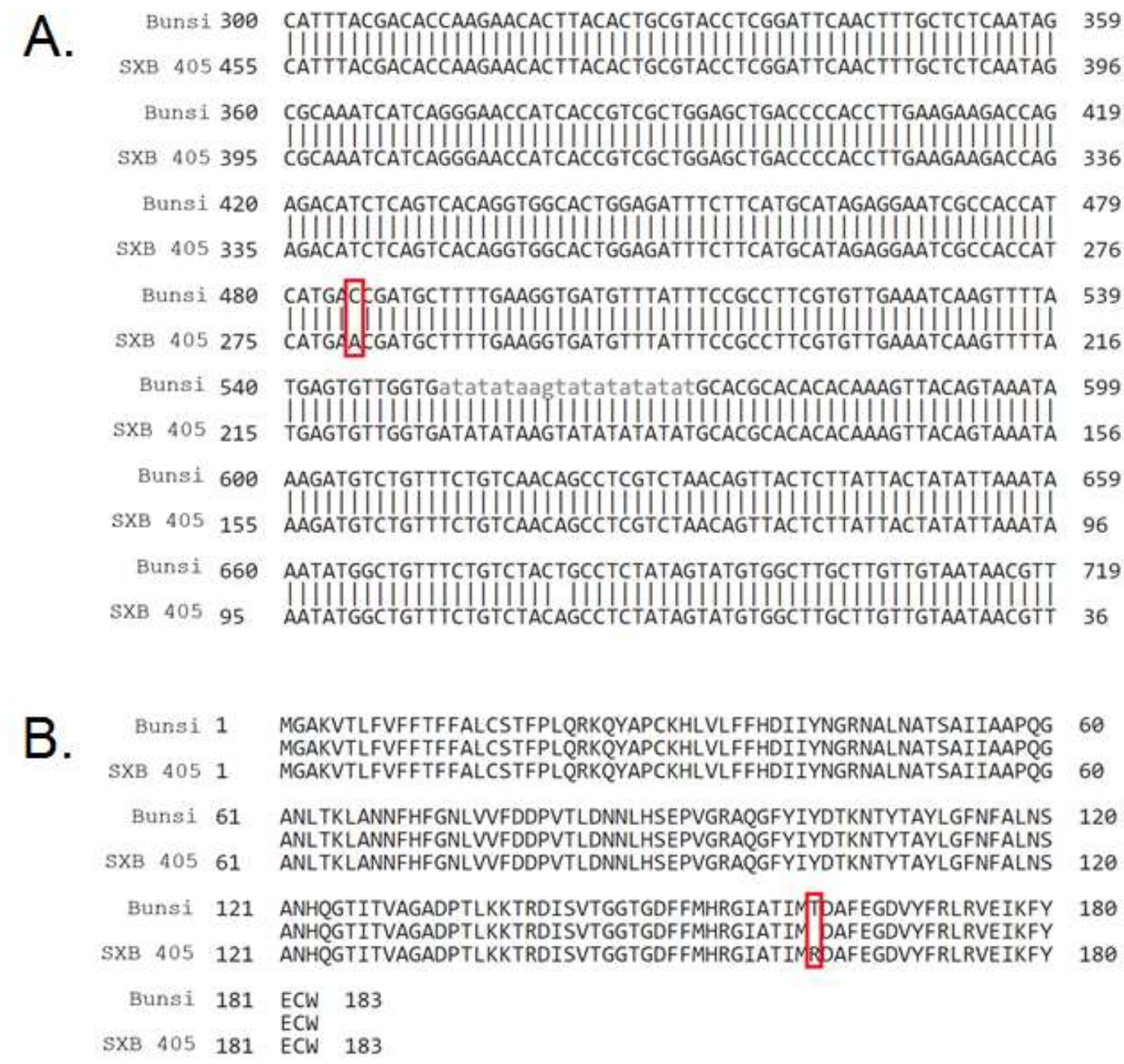

660 Fig. S6. A polymorphism exists in PvPdh1 between the parents of the RI population. A) At 661 position 485 of the CDS of PvPdh1, there is a C/A polymorphism between ICA Bunsi and SXB 662 405. This nonsynonymous substitution leads to $B$ ) a threonine/asparagine polymorphism at 663 position 162 in the amino acid sequence of the protein products. 


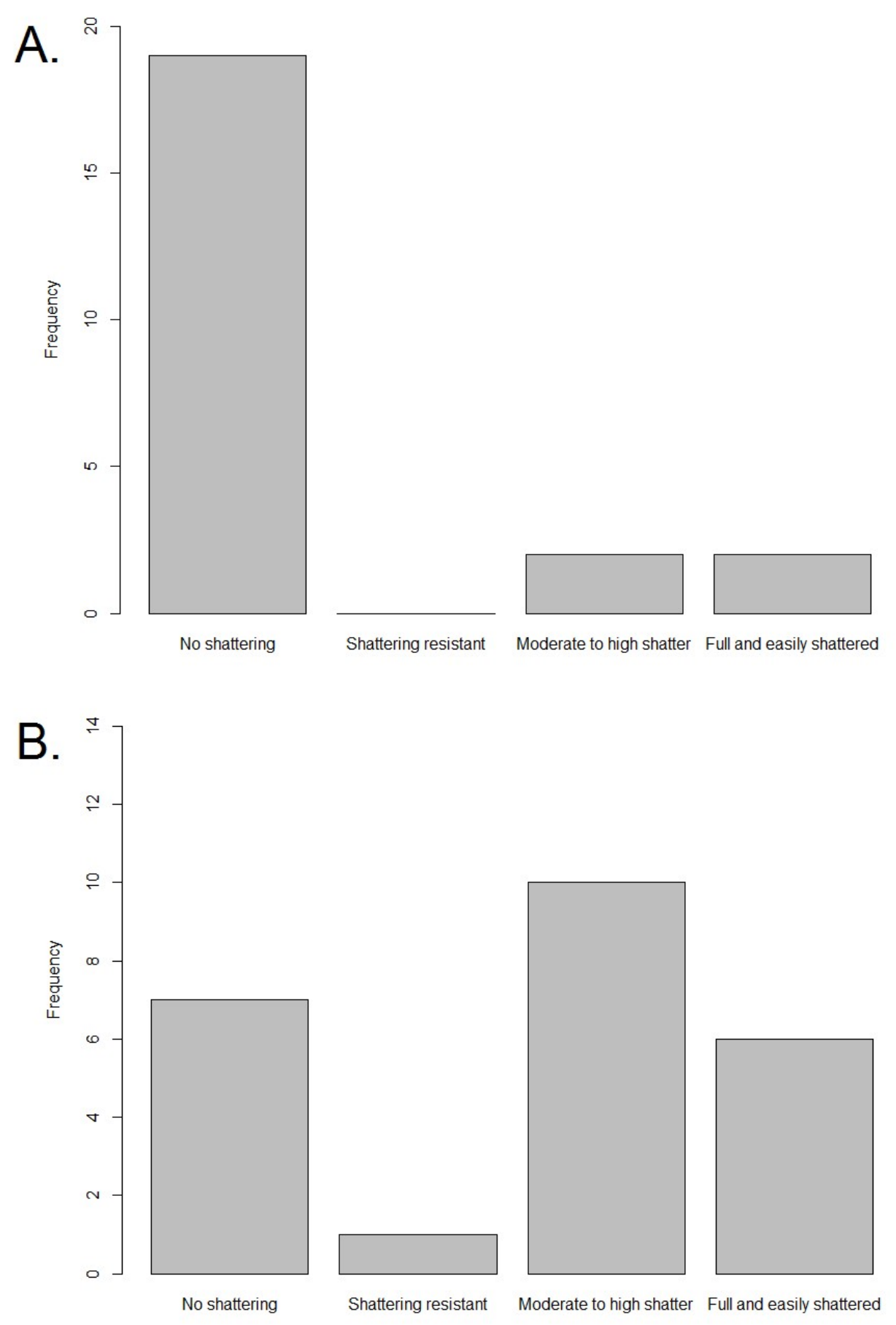

Fig. S7. Dehiscence in Middle American GRIN NPGS accessions. A) In individuals with an asparagine at position 162, dehiscence resistance predominates. B) In individuals with a wildtype threonine at position 162, dehiscence susceptibility predominates. Accessions were phenotyped by GRIN NPGS and genotyped by Sanger sequencing of PvPdh1. 
bioRxiv preprint doi: https://doi.org/10.1101/517516; this version posted January 13,2019 . The copyright holder for this preprint (which was not certified by peer review) is the author/funder. All rights reserved. No reuse allowed without permission.

A.

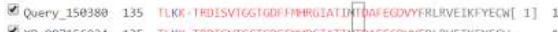

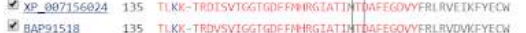

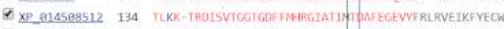

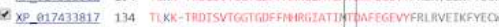

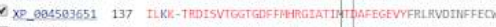

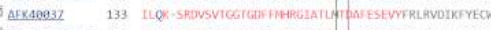

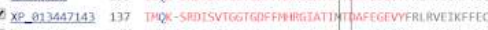

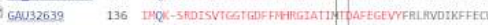

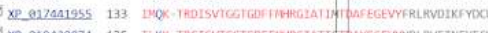

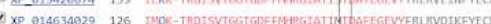

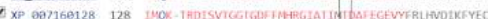

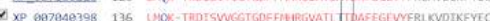

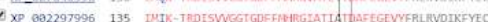

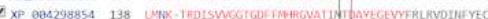

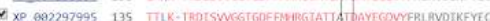

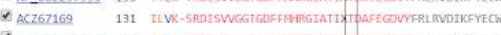

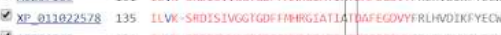

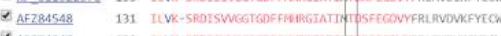

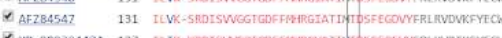

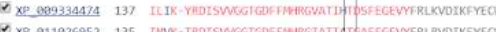

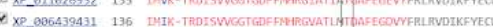

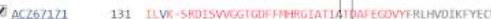

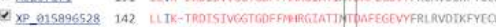

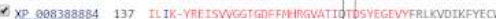

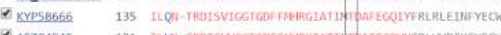

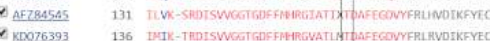

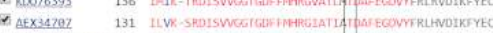

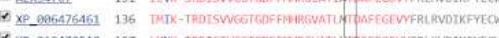

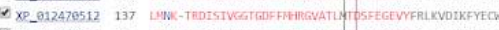

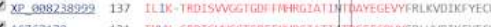

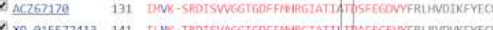

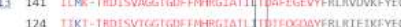

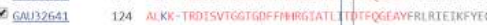

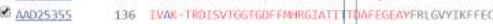

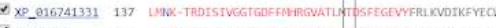

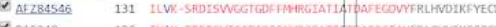

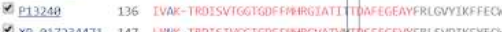

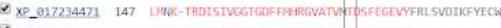

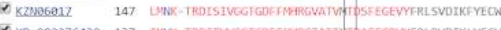

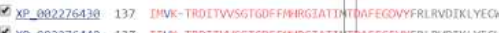

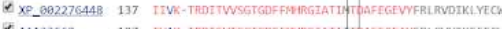

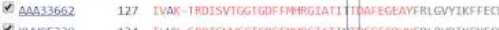

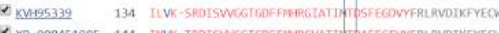

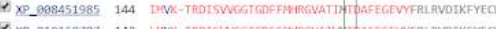

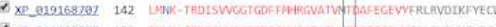

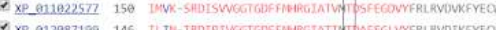

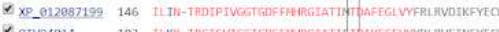

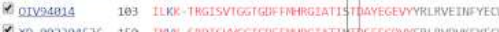

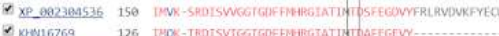

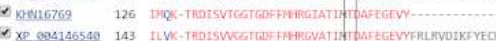

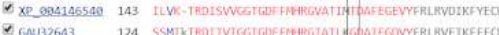

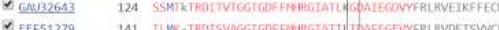

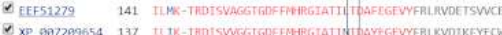

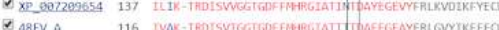

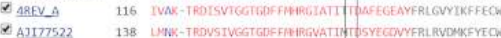

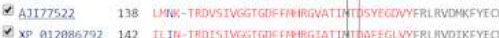

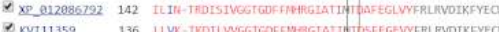

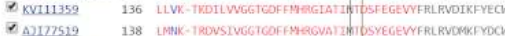

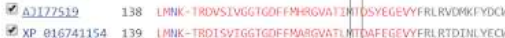

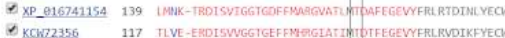

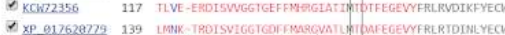

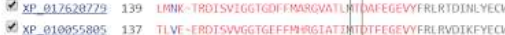

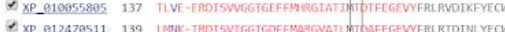

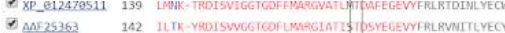

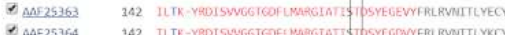

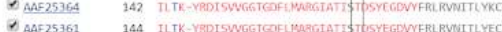

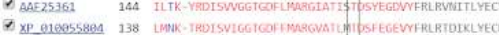

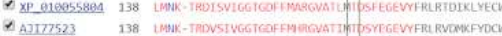

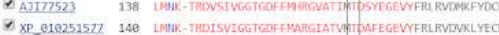

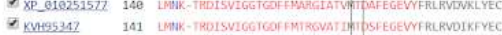

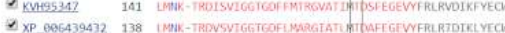

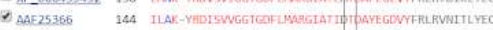

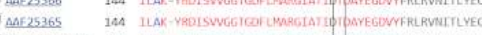

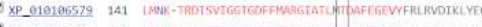

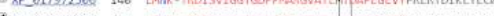

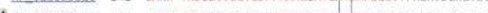
a a mezsea

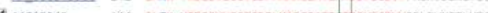

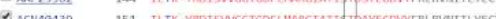

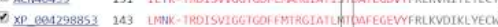

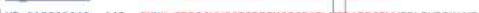

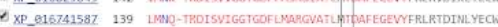

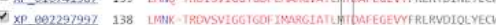

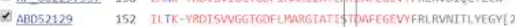

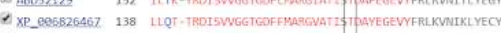

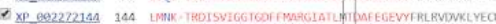

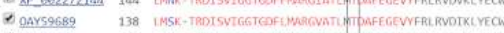

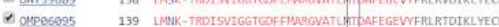

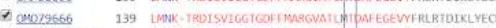

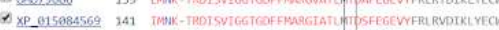

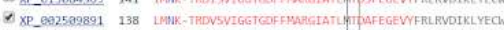

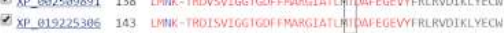

B Query_274211 157 TATIIDDAFEGDVYFRLRVETKF[5] 184

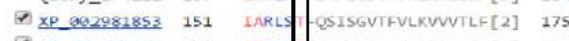
XP_902982822 165 IARL TXP_ADJ976Rด9 2467 TANL HSTDGDTFTUNUTSRIY[4] 2493 C) XP $002980538 \quad 120$ IANLY HSIDGDTFIVNVT-..- 138 - XP 092971526 138 IATI HSTDGDTFIVLFKTKLII[2] 162

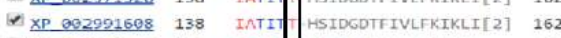
$\checkmark x P \_002974933120$ YAII [1) XP $002993354 \quad 152 \quad$ YAIV

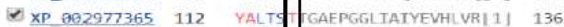

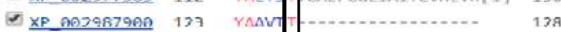
112 YALTS GPAEPGGFIATYEVHL- 133

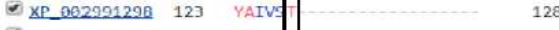
DI XP_002972749 119 YAIVI 7 XP_002989690 141 YATI SASGGSVILEIDVKVSH 164 XP ag29B6379 141 YATIV SASGASVTLETONRVSH 164

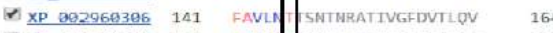

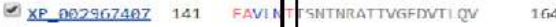
T) XP 002966352 119 FAVI |SSVMHFSAVLHFNVTFOH 142 $\square \times \Gamma_{-002078202} 119$ rAVI

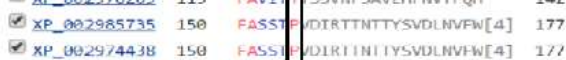
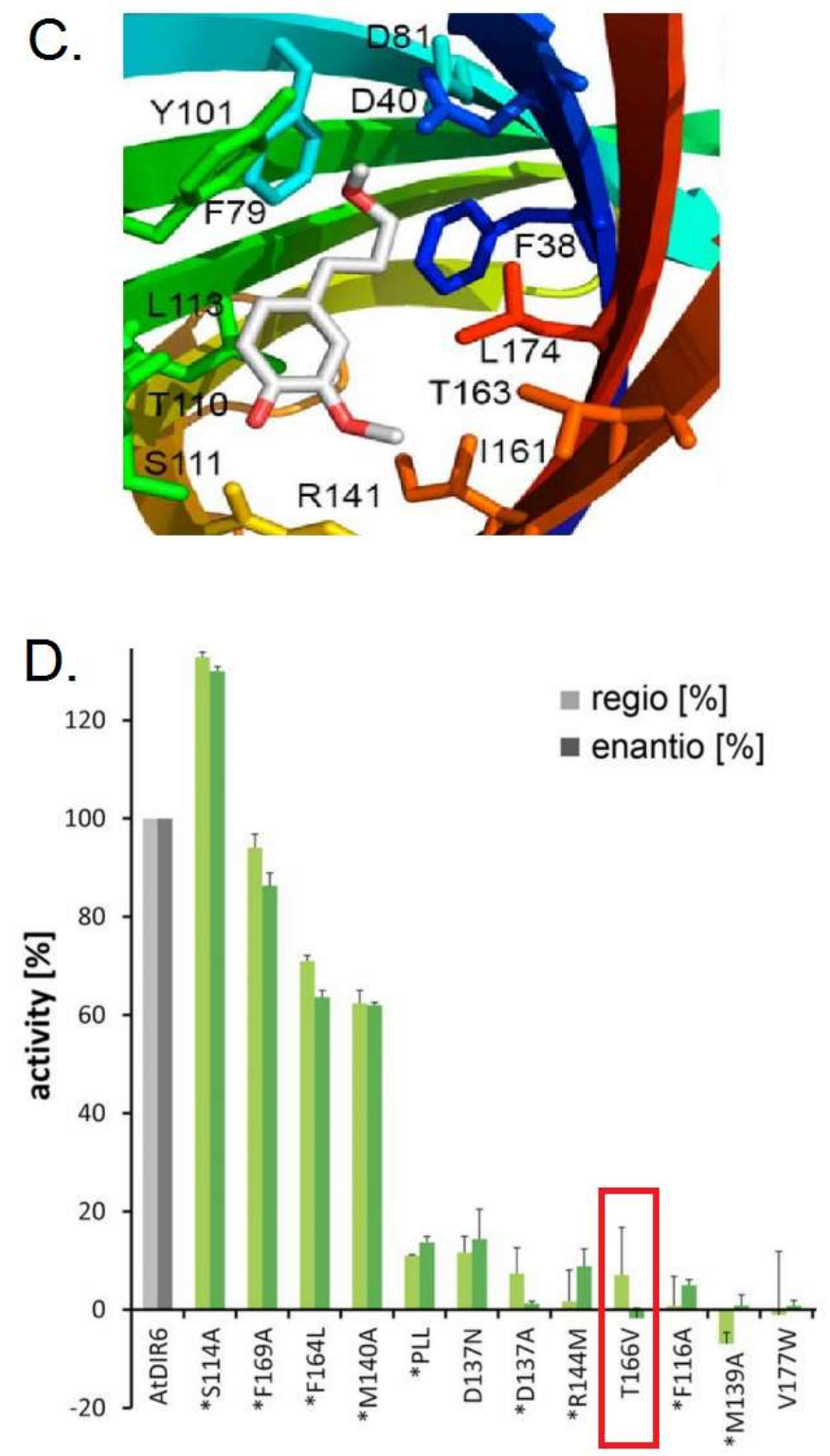
671 Fig. S8. The threonine at position 162 is a highly conserved component of the active site for

672 dirigent-like genes. (A) Of the 100 most similar proteins to PvPDH1 in the NCBI database, 99

673 have a threonine at the aligned position, indicating it is vital for protein functionality. The one

674 exception is a gene from Trifolium subterraneum, which places pods underground and the gene

675 may be undergoing gene decay. (B) The 19 most similar dirigent-like genes from Selaginella

676 moellendorffii have a threonine at this position, indicating that the residue has been very

677 strongly conserved for over 400 million years $(22,23)$. (C) In the closely related protein PsDIR6,

678 the homologous threonine (T163) is an important component of the active site (from (24)). (D)

679 Targeted mutagenesis of the equivalent residue (T166) in a closely related Arabidopsis protein

680 showed that substituting the threonine with a valine led to a complete loss of gene function

681 (from (25)). 


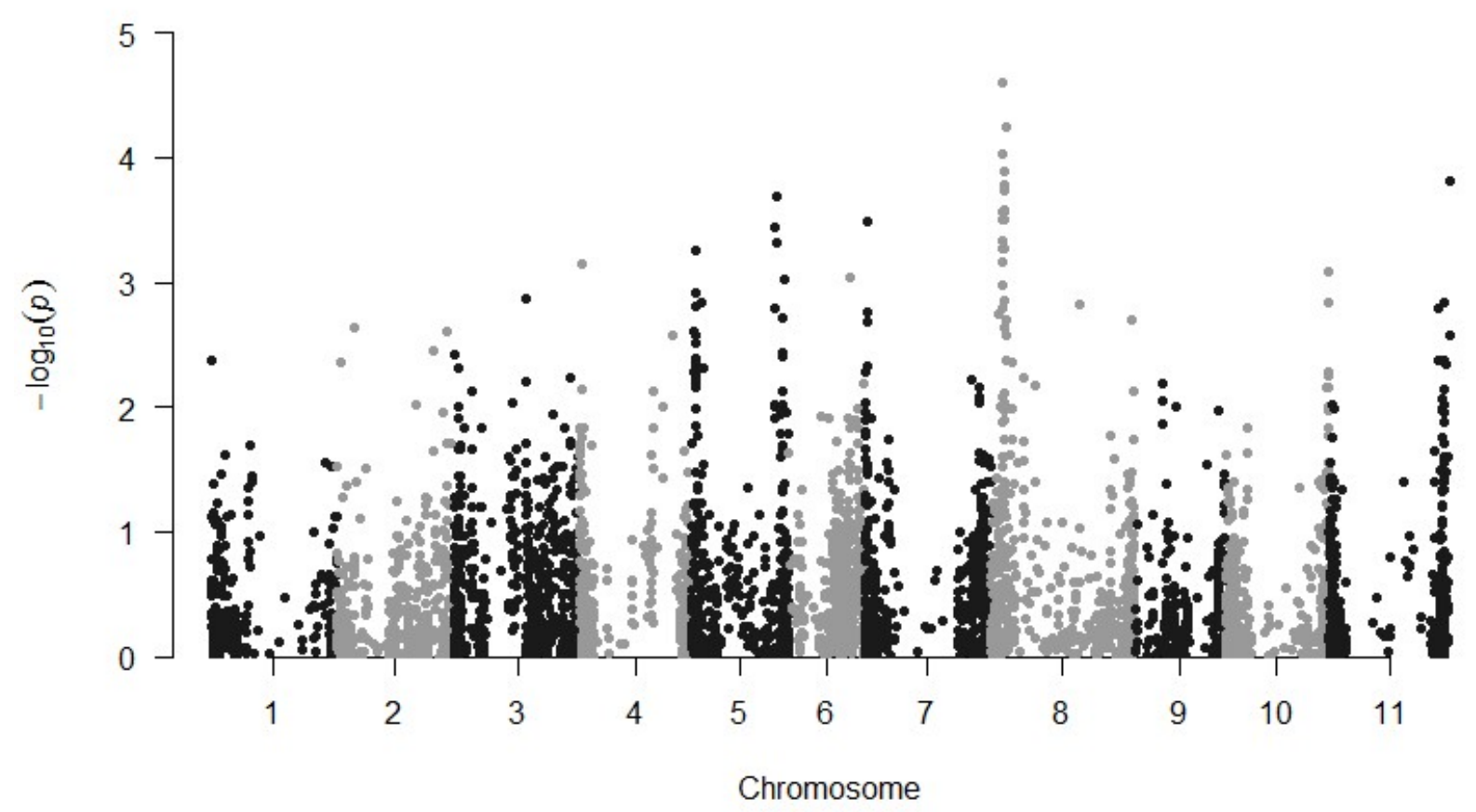

Fig. S9. GWAS of pod dehiscence (PD) in Race Mesoamerica (MDP, PC1>50) using GLM in SNiPlay/TASSEL. Pv08 was most significantly associated with variation in PD, although no SNPs achieved significance in this smaller population, the most significant SNPs were located in an overlapping interval on Pv08 as a major QTL of the ADP, indicating that the same gene may be responsible for the variation across populations. MAF threshold $=0.1$. 
Table S1. Co-segregation between dehiscence phenotype and position 162 in PVPdh1. The 11 RILs with recombination between the flanking markers from QTL mapping showed perfect correspondence between phenotype and genotype at this position.

\begin{tabular}{llcl}
\hline RIL & Phenotype & PvPdh1 CDS residue & PvPDH1 peptide residue 162 \\
\hline 013 & Dehiscent & Cytosine & Threonine \\
036 & Dehiscent & Cytosine & Threonine \\
052 & Dehiscent & Cytosine & Threonine \\
094 & Dehiscent & Cytosine & Threonine \\
096 & Dehiscent & Cytosine & Threonine \\
006 & Non-dehiscent & Adenine & Asparagine \\
033 & Non-dehiscent & Adenine & Asparagine \\
065 & Non-dehiscent & Adenine & Asparagine \\
101 & Non-dehiscent & Adenine & Asparagine \\
117 & Non-dehiscent & Adenine & Asparagine \\
154 & Non-dehiscent & Adenine & Asparagine \\
\hline
\end{tabular}


Table S2. Sequencing of PvPdh1 in several species of wild and domesticated Phaseolus

\begin{tabular}{|c|c|c|c|c|c|c|c|c|c|}
\hline Accession & Species & Primer & $\begin{array}{c}\text { Position } \\
485 \text { C-->A; } \\
\text { Threonine - } \\
\text {-> } \\
\text { Asparagine }\end{array}$ & $\begin{array}{c}\text { Middle } \\
\text { American } \\
\text { or Andean } \\
\text { based on } \\
\text { duplication } \\
\text { of } \\
\text { repetitive } \\
\text { element } \\
\text { near } \\
\text { position } \\
648\end{array}$ & $\begin{array}{l}\text { Source/ } \\
\text { station }\end{array}$ & Shattering & Shattering_2 & Country of origin & $\begin{array}{c}\text { Improvement } \\
\text { status }\end{array}$ \\
\hline PI 477040 & $\begin{array}{c}\mathrm{P} . \\
\text { acutifolius }\end{array}$ & PvPdh1ALL & C & NA & W6 & High shattering & & United States & Wild \\
\hline PI 195359 & $\begin{array}{c}\mathrm{P} . \\
\text { dumosus }\end{array}$ & PvPdh1ALL & C & NA & W6 & Shattering resistant & & Guatemala & Landrace \\
\hline PI 311194 & $\begin{array}{c}\text { P. } \\
\text { dumosus }\end{array}$ & PvPdh1ALL & $\mathrm{C}$ & NA & W6 & Shattering resistant & & Guatemala & Landrace \\
\hline PI 326055 & $\begin{array}{c}P . \\
\text { dumosus }\end{array}$ & PvPdh1ALL & C & NA & W6 & Shattering resistant & & Venezuela & Landrace \\
\hline PI 535379 & P. hintonii & PvPdh1ALL & C & NA & W6 & Full and easily shattered & & Mexico & Wild \\
\hline PI 257418 & P. lunatus & PvPdh1ALL & C & NA & W6 & Moderate to high shattering & & Argentina & Landrace \\
\hline PI 264603 & P. lunatus & PvPdh1ALL & C & NA & W6 & Moderate to high shattering & & Costa Rica & Wild \\
\hline PI 264606 & P. lunatus & PvPdh1ALL & C & NA & W6 & Moderate to high shattering & & Costa Rica & Wild \\
\hline PI 264607 & P. lunatus & PvPdh1ALL & C & NA & W6 & Moderate to high shattering & & Costa Rica & Wild \\
\hline PI 264610 & P. lunatus & PvPdh1ALL & C & NA & W6 & Moderate to high shattering & & Costa Rica & Wild \\
\hline PI 347796 & P. lunatus & PvPdh1ALL & C & NA & W6 & Shattering resistant & & United States & Cultivated \\
\hline PI 347797 & P. lunatus & PvPdh1ALL & C & NA & W6 & Moderate to high shattering & & United States & Cultivated \\
\hline PI 347811 & P. lunatus & PvPdh1ALL & C & NA & W6 & Moderate to high shattering & & United States & Cultivated \\
\hline Canario 707 & P. vulgaris & PvPdh1Andes & C & Andean & Davis & Shattering resistant & & United States & Cultivated \\
\hline Etna & P. vulgaris & PvPdh1Andes & C & Andean & Davis & Moderate to high shatter & & United States & Cultivated \\
\hline PI 136701 & P. vulgaris & PvPdh1ALL & C & Andean & W6 & No shattering & & Canada & Cultivated \\
\hline PI 136745 & P. vulgaris & PvPdh1ALL & C & Andean & W6 & No shattering & & Canada & Cultivar \\
\hline PI 161952 & P. vulgaris & PvPdh1ALL & C & Andean & W6 & No shattering & & Belgium & Cultivated \\
\hline PI 167105 & P. vulgaris & PvPdh1ALL & $\mathrm{C}$ & Andean & W6 & No shattering & & Turkey & Cultivated \\
\hline PI 169804 & P. vulgaris & PvPdh1ALL & $\mathrm{C}$ & Andean & W6 & No shattering & & Turkey & Cultivated \\
\hline
\end{tabular}

39 | P a g e 


\begin{tabular}{|c|c|c|c|c|c|c|c|c|c|}
\hline Accession & Species & Primer & $\begin{array}{c}\text { Position } \\
485 \text { C-->A; } \\
\text { Threonine - } \\
\text {-> } \\
\text { Asparagine }\end{array}$ & $\begin{array}{c}\text { Middle } \\
\text { American } \\
\text { or Andean } \\
\text { based on } \\
\text { duplication } \\
\text { of } \\
\text { repetitive } \\
\text { element } \\
\text { near } \\
\text { position } \\
648\end{array}$ & $\begin{array}{l}\text { Sourcel } \\
\text { station }\end{array}$ & Shattering & Shattering_2 & Country of origin & $\begin{array}{l}\text { Improvemen } \\
\text { status }\end{array}$ \\
\hline PI 180734 & P. vulgaris & PvPdh1ALL & C & Andean & W6 & No shattering & & Germany & Cultivar \\
\hline PI 226859 & P. vulgaris & PvPdh1ALL & C & Andean & W6 & No shattering & & Spain & Cultivar \\
\hline PI 226879 & P. vulgaris & PvPdh1ALL & C & Andean & W6 & No shattering & & Ukraine & Cultivated \\
\hline PI 226934 & P. vulgaris & PvPdh1ALL & C & Andean & W6 & No shattering & & Germany & Cultivated \\
\hline PI 234257 & P. vulgaris & PvPdh1ALL & C & Andean & W6 & No shattering & & Turkey & Cultivated \\
\hline PI 278689 & P. vulgaris & PvPdh1ALL & C & Andean & W6 & No shattering & & United States & Cultivated \\
\hline PI 279818 & P. vulgaris & PvPdh1ALL & C & Andean & W6 & No shattering & & Canada & Cultivar \\
\hline PI 281596 & P. vulgaris & PvPdh1ALL & C & Andean & W6 & No shattering & & Italy & Cultivated \\
\hline PI 289355 & P. vulgaris & PvPdh1ALL & C & Andean & W6 & No shattering & & Hungary & Cultivar \\
\hline PI 304813 & P. vulgaris & PvPdh1ALL & C & Andean & W6 & Moderate to high shattering & & United States & $\begin{array}{c}\text { Breeding } \\
\text { material }\end{array}$ \\
\hline PI 304824 & P. vulgaris & PvPdh1ALL & C & Andean & W6 & Moderate to high shatter & & United States & $\begin{array}{l}\text { Breeding } \\
\text { material }\end{array}$ \\
\hline PI 309766 & P. vulgaris & PvPdh1ALL & C & Andean & W6 & Moderate to high shatter & & Mexico & Landrace \\
\hline PI 313270 & P. vulgaris & PvPdh1ALL & C & Andean & W6 & Moderate to high shatter & $\begin{array}{l}\text { Full and } \\
\text { easily } \\
\text { shattered }\end{array}$ & Mexico & Landrace \\
\hline PI 324628 & P. vulgaris & PvPdh1ALL & C & Andean & W6 & No shattering & & Hungary & Cultivar \\
\hline PI 325630 & P. vulgaris & PvPdh1ALL & C & Andean & W6 & No shattering & & Mexico & Landrace \\
\hline PI 353500 & P. vulgaris & PvPdh1ALL & C & Andean & W6 & No shattering & & China & Cultivated \\
\hline PI 353531 & P. vulgaris & PvPdh1ALL & C & Andean & W6 & No shattering & & China & Cultivated \\
\hline PI 361284 & P. vulgaris & PvPdh1ALL & C & Andean & W6 & Full and easily shattered & & India & Uncertain \\
\hline PI 433622 & P. vulgaris & PvPdh1ALL & C & Andean & W6 & Moderate to high shatter & & United States & Cultivar \\
\hline
\end{tabular}

40 | P a g e 


\begin{tabular}{|c|c|c|c|c|c|c|c|c|c|}
\hline Accession & Species & Primer & $\begin{array}{c}\text { Position } \\
485 \text { C-->A; } \\
\text { Threonine - } \\
\text {-> } \\
\text { Asparagine }\end{array}$ & $\begin{array}{c}\text { Middle } \\
\text { American } \\
\text { or Andean } \\
\text { based on } \\
\text { duplication } \\
\text { of } \\
\text { repetitive } \\
\text { element } \\
\text { near } \\
\text { position } \\
648\end{array}$ & $\begin{array}{l}\text { Source/ } \\
\text { station }\end{array}$ & Shattering & Shattering_2 & Country of origin & $\begin{array}{c}\text { Improvement } \\
\text { status }\end{array}$ \\
\hline PI 439555 & P. vulgaris & PvPdh1ALL & $\mathrm{C}$ & Andean & W6 & Moderate to high shatter & & Netherlands & Landrace \\
\hline PI 439571 & P. vulgaris & PvPdh1ALL & C & Andean & W6 & Moderate to high shatter & & Netherlands & Landrace \\
\hline PI 476686 & P. vulgaris & PvPdh1ALL & C & Andean & W6 & Full and easily shattered & & Mexico & Cultivated \\
\hline PI 533322 & P. vulgaris & PvPdh1ALL & C & Andean & W6 & Moderate to high shatter & & Mexico & Cultivated \\
\hline PI 533323 & P. vulgaris & PvPdh1ALL & $\mathrm{C}$ & Andean & W6 & Moderate to high shatter & & Mexico & Cultivated \\
\hline PI 632356 & P. vulgaris & PvPdh1ALL & C & Andean & W6 & Full and easily shattered & & United States & Cultivated \\
\hline Tiger's Eye & P. vulgaris & PvPdh1Andes & C & Andean & Davis & Moderate to high shatter & & United States & Landrace \\
\hline UC 0801 & P. vulgaris & PvPdh1Andes & C & Andean & Davis & No shattering & & United States & Cultivated \\
\hline UC Holstein & P. vulgaris & PvPdh1Andes & C & Andean & Davis & No shattering & & United States & Cultivated \\
\hline $\begin{array}{l}\text { UC Jacob's } \\
\text { Cattle }\end{array}$ & P. vulgaris & PvPdh1ALL & C & Andean & Davis & No shattering & & United States & Cultivated \\
\hline Matterhorn & P. vulgaris & PvPdh1ALL & A & $\begin{array}{c}\text { Middle } \\
\text { American }\end{array}$ & Davis & No shattering & & United States & Cultivar \\
\hline PI 136722 & P. vulgaris & PvPdh1ALL & A & $\begin{array}{c}\text { Middle } \\
\text { American }\end{array}$ & W6 & No shattering & & Canada & Cultivated \\
\hline PI 169722 & P. vulgaris & PvPdh1ALL & A & $\begin{array}{c}\text { Middle } \\
\text { American }\end{array}$ & W6 & No shattering & & Turkey & Cultivated \\
\hline PI 169725 & P. vulgaris & PvPdh1ALL & A & $\begin{array}{c}\text { Middle } \\
\text { American }\end{array}$ & W6 & No shattering & & Turkey & Landrace \\
\hline PI 169731 & P. vulgaris & PvPdh1ALL & A & $\begin{array}{c}\text { Middle } \\
\text { American }\end{array}$ & W6 & No shattering & & Turkey & Cultivated \\
\hline
\end{tabular}

41 | P a g e 


\begin{tabular}{|c|c|c|c|c|c|c|c|c|c|}
\hline Accession & Species & Primer & $\begin{array}{c}\text { Position } \\
485 \text { C-->A; } \\
\text { Threonine - } \\
\text {-> } \\
\text { Asparagine }\end{array}$ & $\begin{array}{c}\text { Middle } \\
\text { American } \\
\text { or Andean } \\
\text { based on } \\
\text { duplication } \\
\text { of } \\
\text { repetitive } \\
\text { element } \\
\text { near } \\
\text { position } \\
648\end{array}$ & $\begin{array}{l}\text { Source/ } \\
\text { station }\end{array}$ & Shattering & Shattering_2 & Country of origin & $\begin{array}{c}\text { Improvement } \\
\text { status }\end{array}$ \\
\hline PI 175866 & P. vulgaris & PvPdh1ALL & A & $\begin{array}{c}\text { Middle } \\
\text { American }\end{array}$ & W6 & No shattering & & Turkey & Cultivated \\
\hline PI 289341 & P. vulgaris & PvPdh1ALL & A & $\begin{array}{c}\text { Middle } \\
\text { American }\end{array}$ & W6 & No shattering & & Hungary & Cultivar \\
\hline PI 289342 & P. vulgaris & PvPdh1ALL & A & $\begin{array}{c}\text { Middle } \\
\text { American }\end{array}$ & W6 & No shattering & & Hungary & Cultivar \\
\hline PI 289358 & P. vulgaris & PvPdh1ALL & $A$ & $\begin{array}{c}\text { Middle } \\
\text { American }\end{array}$ & W6 & No shattering & & Hungary & Cultivar \\
\hline PI 291368 & P. vulgaris & PvPdh1ALL & $A$ & $\begin{array}{c}\text { Middle } \\
\text { American }\end{array}$ & W6 & No shattering & & China & Cultivated \\
\hline PI 309729 & P. vulgaris & PvPdh1ALL & A & $\begin{array}{c}\text { Middle } \\
\text { American }\end{array}$ & W6 & Moderate to high shatter & & Mexico & Landrace \\
\hline PI 311907 & P. vulgaris & PvPdh1ALL & A & $\begin{array}{c}\text { Middle } \\
\text { American }\end{array}$ & W6 & Moderate to high shattering & & Mexico & Landrace \\
\hline PI 313309 & P. vulgaris & PvPdh1ALL & A & $\begin{array}{c}\text { Middle } \\
\text { American }\end{array}$ & W6 & Full and easily shattered & & Mexico & Landrace \\
\hline PI 313313 & P. vulgaris & PvPdh1ALL & A & $\begin{array}{c}\text { Middle } \\
\text { American }\end{array}$ & W6 & No shattering & & Mexico & Landrace \\
\hline PI 324580 & P. vulgaris & PvPdh1ALL & A & $\begin{array}{c}\text { Middle } \\
\text { American }\end{array}$ & W6 & No shattering & & Hungary & Cultivar \\
\hline PI 324593 & P. vulgaris & PvPdh1ALL & A & $\begin{array}{c}\text { Middle } \\
\text { American }\end{array}$ & W6 & No shattering & & Hungary & Cultivar \\
\hline PI 324604 & P. vulgaris & PvPdh1ALL & A & $\begin{array}{c}\text { Middle } \\
\text { American }\end{array}$ & W6 & No shattering & & Hungary & Cultivar \\
\hline PI 353505 & P. vulgaris & PvPdh1ALL & A & $\begin{array}{c}\text { Middle } \\
\text { American }\end{array}$ & W6 & No shattering & & China & Cultivated \\
\hline Pink 9634 & P. vulgaris & PvPdh1ALL & $A$ & $\begin{array}{c}\text { Middle } \\
\text { American }\end{array}$ & Davis & No shattering & & United States & Cultivar \\
\hline
\end{tabular}

42 | P a g e 


\begin{tabular}{|c|c|c|c|c|c|c|c|c|c|}
\hline Accession & Species & Primer & $\begin{array}{c} \\
\text { Position } \\
485 \text { C-->A; } \\
\text { Threonine - } \\
\text {-> } \\
\text { Asparagine }\end{array}$ & $\begin{array}{c}\text { Middle } \\
\text { American } \\
\text { or Andean } \\
\text { based on } \\
\text { duplication } \\
\text { of } \\
\text { repetitive } \\
\text { element } \\
\text { near } \\
\text { position } \\
648\end{array}$ & $\begin{array}{l}\text { Source/ } \\
\text { station }\end{array}$ & Shattering & Shattering_2 & Country of origin & $\begin{array}{c}\text { Improvement } \\
\text { status }\end{array}$ \\
\hline W6 27625 & P. vulgaris & PvPdh1ALL & A & $\begin{array}{c}\text { Middle } \\
\text { American }\end{array}$ & W6 & Full and easily shattered & & Mexico & $\begin{array}{c}\text { Labeled as wild, } \\
\text { but has solid black } \\
\text { seeds that weigh } \\
38 \mathrm{~g} / 100\end{array}$ \\
\hline W6 9719 & P. vulgaris & PvPdh1ALL & $A$ & $\begin{array}{c}\text { Middle } \\
\text { American }\end{array}$ & W6 & No shattering & & $\begin{array}{l}\text { Russian } \\
\text { Federation }\end{array}$ & Cultivar \\
\hline Zuni Gold & P. vulgaris & PvPdh1ALL & A & $\begin{array}{c}\text { Middle } \\
\text { American }\end{array}$ & Davis & No shattering & & United States & Landrace \\
\hline SXB 405 & P. vulgaris & PvPdh1ALL & $A$ & $\begin{array}{c}\text { Middle } \\
\text { American }\end{array}$ & Davis & Non-shattering & & & Cultivated \\
\hline PI 194572 & P. vulgaris & PvPdh1ALL & C & $\begin{array}{c}\text { Middle } \\
\text { American }\end{array}$ & W6 & Full and easily shattered & & Guatemala & Landrace \\
\hline PI 227115 & P. vulgaris & PvPdh1ALL & C & $\begin{array}{c}\text { Middle } \\
\text { American }\end{array}$ & W6 & No shattering & & Australia & Cultivated \\
\hline PI 262977 & P. vulgaris & PvPdh1ALL & $\mathrm{C}$ & $\begin{array}{c}\text { Middle } \\
\text { American }\end{array}$ & W6 & No shattering & & Netherlands & Cultivated \\
\hline PI 282057 & P. vulgaris & PvPdh1ALL & C & $\begin{array}{c}\text { Middle } \\
\text { American }\end{array}$ & W6 & No shattering & & Chile & Cultivar \\
\hline PI 307820 & P. vulgaris & PvPdh1ALL & C & $\begin{array}{c}\text { Middle } \\
\text { American }\end{array}$ & W6 & Moderate to high shattering & & El Salvador & Landrace \\
\hline PI 310586 & P. vulgaris & PvPdh1ALL & C & $\begin{array}{c}\text { Middle } \\
\text { American }\end{array}$ & W6 & Moderate to high shatter & & Honduras & Cultivated \\
\hline PI 311843 & P. vulgaris & PvPdh1ALL & C & $\begin{array}{c}\text { Middle } \\
\text { American }\end{array}$ & W6 & Shattering resistant & & Guatemala & Landrace \\
\hline PI 313572 & P. vulgaris & PvPdh1ALL & C & $\begin{array}{c}\text { Middle } \\
\text { American }\end{array}$ & W6 & Full and easily shattered & & Colombia & Cultivated \\
\hline
\end{tabular}

43| Page 


\begin{tabular}{|c|c|c|c|c|c|c|c|c|c|}
\hline Accession & Species & Primer & $\begin{array}{c} \\
\\
\text { Position } \\
485 \text { C-->A; } \\
\text { Threonine - } \\
-> \\
\text { Asparagine }\end{array}$ & $\begin{array}{c}\text { Middle } \\
\text { American } \\
\text { or Andean } \\
\text { based on } \\
\text { duplication } \\
\text { of } \\
\text { repetitive } \\
\text { element } \\
\text { near } \\
\text { position } \\
648\end{array}$ & $\begin{array}{l}\text { Sourcel } \\
\text { station }\end{array}$ & Shattering & Shattering_2 & Country of origin & $\begin{array}{c}\text { Improvement } \\
\text { status }\end{array}$ \\
\hline PI 324618 & P. vulgaris & PvPdh1ALL & C & $\begin{array}{c}\text { Middle } \\
\text { American }\end{array}$ & W6 & No shattering & & Hungary & Cultivar \\
\hline PI 358218 & P. vulgaris & PvPdh1ALL & C & $\begin{array}{c}\text { Middle } \\
\text { American }\end{array}$ & W6 & No shattering & & Macedonia & Cultivar \\
\hline PI 476681 & P. vulgaris & PvPdh1ALL & C & $\begin{array}{c}\text { Middle } \\
\text { American }\end{array}$ & W6 & Moderate to high shatter & & Mexico & Cultivated \\
\hline PI 476688 & P. vulgaris & PvPdh1ALL & C & $\begin{array}{c}\text { Middle } \\
\text { American }\end{array}$ & W6 & Moderate to high shatter & & Mexico & Cultivated \\
\hline PI 476694 & P. vulgaris & PvPdh1ALL & C & $\begin{array}{c}\text { Middle } \\
\text { American }\end{array}$ & W6 & Moderate to high shatter & & Mexico & Cultivated \\
\hline PI 476695 & P. vulgaris & PvPdh1ALL & C & $\begin{array}{c}\text { Middle } \\
\text { American }\end{array}$ & W6 & Moderate to high shatter & & Mexico & Cultivated \\
\hline PI 476701 & P. vulgaris & PvPdh1ALL & C & $\begin{array}{c}\text { Middle } \\
\text { American }\end{array}$ & W6 & Moderate to high shatter & & Mexico & Cultivated \\
\hline PI 476703 & P. vulgaris & PvPdh1ALL & C & $\begin{array}{c}\text { Middle } \\
\text { American }\end{array}$ & W6 & Full and easily shattered & & Mexico & Cultivated \\
\hline PI 476707 & P. vulgaris & PvPdh1ALL & C & $\begin{array}{c}\text { Middle } \\
\text { American }\end{array}$ & W6 & Moderate to high shatter & & Guatemala & Cultivated \\
\hline PI 476709 & P. vulgaris & PvPdh1ALL & C & $\begin{array}{c}\text { Middle } \\
\text { American }\end{array}$ & W6 & Moderate to high shatter & & Guatemala & Cultivated \\
\hline PI 476710 & P. vulgaris & PvPdh1ALL & C & $\begin{array}{c}\text { Middle } \\
\text { American }\end{array}$ & W6 & Moderate to high shatter & & Guatemala & Cultivated \\
\hline PI 476730 & P. vulgaris & PvPdh1ALL & C & $\begin{array}{c}\text { Middle } \\
\text { American }\end{array}$ & W6 & No shattering & & Guatemala & Cultivated \\
\hline PI 476737 & P. vulgaris & PvPdh1ALL & C & $\begin{array}{c}\text { Middle } \\
\text { American }\end{array}$ & W6 & Moderate to high shatter & & Guatemala & Cultivated \\
\hline PI 642946 & P. vulgaris & PvPdh1ALL & C & $\begin{array}{c}\text { Middle } \\
\text { American }\end{array}$ & W6 & Full and easily shattered & & United States & Cultivated \\
\hline
\end{tabular}

44 I P a g e 


\begin{tabular}{|c|c|c|c|c|c|c|c|c|c|}
\hline Accession & Species & Primer & $\begin{array}{c}\text { Position } \\
485 \text { C-->A; } \\
\text { Threonine - } \\
\text {-> } \\
\text { Asparagine }\end{array}$ & $\begin{array}{c}\text { Middle } \\
\text { American } \\
\text { or Andean } \\
\text { based on } \\
\text { duplication } \\
\text { of } \\
\text { repetitive } \\
\text { element } \\
\text { near } \\
\text { position } \\
648\end{array}$ & $\begin{array}{l}\text { Source/ } \\
\text { station }\end{array}$ & Shattering & Shattering_2 & Country of origin & $\begin{array}{c}\text { Improvement } \\
\text { status }\end{array}$ \\
\hline PI 642947 & P. vulgaris & PvPdh1ALL & $\mathrm{C}$ & $\begin{array}{c}\text { Middle } \\
\text { American }\end{array}$ & W6 & Moderate to high shattering & $\begin{array}{l}\text { Full and } \\
\text { easily } \\
\text { shattered }\end{array}$ & United States & Cultivated \\
\hline PI 661740 & P. vulgaris & PvPdh1ALL & C & $\begin{array}{c}\text { Middle } \\
\text { American }\end{array}$ & W6 & Full and easily shattered & & Honduras & Landrace \\
\hline W6 11336 & P. vulgaris & PvPdh1ALL & $\mathrm{C}$ & $\begin{array}{c}\text { Middle } \\
\text { American }\end{array}$ & W6 & No shattering & & China & Cultivar \\
\hline G12873 & P. vulgaris & PvPdh1ALL & C & $\begin{array}{c}\text { Middle } \\
\text { American }\end{array}$ & Davis & Full and easily shattered & & Mexico & Wild \\
\hline ICA Bunsi & P. vulgaris & PvPdh1ALL & $\mathrm{C}$ & $\begin{array}{c}\text { Middle } \\
\text { American }\end{array}$ & Davis & Shattering & & Colombia & Cultivated \\
\hline PI 339544 & P. vulgaris & PvPdh1ALL & $\begin{array}{c}\text { "M" } \\
\text { ambiguity } \\
\text { code. } \\
\text { Exluded } \\
\text { from } \\
\text { analysis }\end{array}$ & $\begin{array}{c}\text { Middle } \\
\text { American }\end{array}$ & W6 & No shattering & & Turkey & Landrace \\
\hline PI 226900 & P. vulgaris & PvPdh1ALL & C & NA & W6 & No shattering & & Spain & Cultivated \\
\hline PI 433561 & P. vulgaris & PvPdh1ALL & C & NA & W6 & Moderate to high shatter & & United States & Cultivar \\
\hline G23584 & $\begin{array}{c}\text { P. } \\
\text { debouckii }\end{array}$ & PvPdh1Andes & C & Andean & Davis & Shattering & & Peru & Wild \\
\hline
\end{tabular}


Table S3. Synteny near Pdh1 in G. max and P. vulgaris - sharing of gene models.

\begin{tabular}{|c|c|c|c|}
\hline \multicolumn{2}{|r|}{ Glycine $\max$} & \multicolumn{2}{|c|}{ Phaseolus vulgaris } \\
\hline Gene model & Predicted gene function & Gene model & Predicted gene function \\
\hline Glyma16g25490.1 & $\begin{array}{l}\text { Proline-rich extensin-like receptor } \\
\text { kinase } 4\end{array}$ & Phvul.003G252900.1 & $\begin{array}{l}\text { Proline-rich extensin-like } \\
\text { receptor kinase } 4\end{array}$ \\
\hline Glyma16g25500.1 & $\begin{array}{l}\text { Leucine-rich repeat (LRR) family } \\
\text { protein }\end{array}$ & Phvul.003G252700.1 & $\begin{array}{l}\text { Leucine-rich repeat (LRR) } \\
\text { family protein }\end{array}$ \\
\hline Glyma16g25530.2 & $\begin{array}{l}\text { Plant invertase/pectin } \\
\text { methylesterase inhibitor } \\
\text { superfamily protein }\end{array}$ & & \\
\hline Glyma16g25540.1 & $\begin{array}{l}\text { Major facilitator superfamily } \\
\text { protein }\end{array}$ & Phvul.003G252500.1 & $\begin{array}{c}\text { Major facilitator superfamily } \\
\text { protein }\end{array}$ \\
\hline Glyma16g25550.1 & $\mathrm{C} 2 \mathrm{H} 2$-like zinc finger protein & Phvul.003G252400.1 & $\begin{array}{l}\mathrm{C} 2 \mathrm{H} 2 \text {-like zinc finger } \\
\text { protein }\end{array}$ \\
\hline Glyma16g25560.1 & $\begin{array}{l}\text { Protein phosphatase } 2 \mathrm{C} \text { family } \\
\text { protein }\end{array}$ & Phvul.003G252300.1 & $\begin{array}{l}\text { Protein phosphatase } 2 \mathrm{C} \\
\text { family protein }\end{array}$ \\
\hline Glyma16g25570.1 & GRAS family transcription factor & Phvul.003G252200.1 & $\begin{array}{l}\text { GRAS family transcription } \\
\text { factor }\end{array}$ \\
\hline Glyma16g25580.1 & $\begin{array}{c}\text { Disease resistance-responsive } \\
\text { (dirigent-like protein) family } \\
\text { protein }\end{array}$ & Phvul.003G252100.1 & $\begin{array}{l}\text { Disease resistance- } \\
\text { responsive (dirigent-like } \\
\text { protein) family protein }\end{array}$ \\
\hline Glyma16g25600.1 & G-box binding factor 1 & & \\
\hline Glyma16g25600.5 & G-box binding factor 1 & Phvul.003G252000.1 & G-box binding factor 1 \\
\hline Glyma16g25600.4 & G-box binding factor 1 & & \\
\hline Glyma16g25600.6 & G-box binding factor 1 & & \\
\hline Glyma16g25600.7 & G-box binding factor 1 & & \\
\hline Glyma16g25611.1 & Protein kinase superfamily protein & Phvul.003G251900.1 & $\begin{array}{l}\text { Protein kinase superfamily } \\
\text { protein }\end{array}$ \\
\hline Glyma16g25620.1 & $\begin{array}{c}\text { geranylgeranyl pyrophosphate } \\
\text { synthase } 1\end{array}$ & Phvul.003G251500.1 & $\begin{array}{c}\text { geranylgeranyl } \\
\text { pyrophosphate synthase } 1\end{array}$ \\
\hline Glyma16g25650.1 & $\begin{array}{l}\text { Protein of unknown function } \\
\text { (DUF677) }\end{array}$ & & \\
\hline \multicolumn{4}{|l|}{ Glyma16g25660.1 } \\
\hline \multicolumn{4}{|l|}{ Glyma16g25670.1 } \\
\hline Glyma16g25680.2 & $\begin{array}{l}\text { Protein of unknown function } \\
\text { (DUF607) }\end{array}$ & Phvul.003G251400.1 & $\begin{array}{l}\text { Protein of unknown function } \\
\text { (DUF607) }\end{array}$ \\
\hline
\end{tabular}




\begin{tabular}{cccc} 
Glyma16g25690.1 & $\begin{array}{c}\text { GNS1/SUR4 membrane protein } \\
\text { family }\end{array}$ & Phvul.003G251300.1 & $\begin{array}{c}\text { GNS1/SUR4 membrane } \\
\text { protein family }\end{array}$ \\
Glyma16g25700.1 & $\begin{array}{c}\text { PQ-loop repeat family protein / } \\
\text { transmembrane family protein }\end{array}$ & Phvul.003G251100.1 & $\begin{array}{c}\text { PQ-loop repeat family } \\
\text { protein / transmembrane } \\
\text { family protein }\end{array}$ \\
Glyma16g25710.2 & Pectin lyase-like superfamily \\
protein & $\begin{array}{c}\text { calmodulin-like 41 } \\
\text { Glyma16g25720.1 }\end{array}$ & Phvul.003G251000.1 & calmodulin-like 41 \\
Glyma16g25740.2 & vacuolar ATP synthase subunit $\mathrm{H}$ & Phvul.003G250900.1 & $\begin{array}{c}\text { vacuolar ATP synthase } \\
\text { subunit H family protein }\end{array}$ \\
\hline
\end{tabular}


Table S4. PD after desiccation, by market class, gene pool, and ecogeographic race

\begin{tabular}{ccccccc}
\hline Market class & Gene pool & Race & $\begin{array}{c}\text { Mean PD } \\
(\%)\end{array}$ & $\begin{array}{c}\text { Median PD } \\
\text { (\%) }\end{array}$ & $\begin{array}{c}\text { Standard } \\
\text { deviation (\%) }\end{array}$ & $\mathbf{n}$ \\
\hline Cranberry & Andean & Nueva Granada & 41.43 & 46.29 & 29.86 & 24 \\
Kidney & Andean & Nueva Granada & 21.09 & 13.89 & 18.32 & 43 \\
Purple speck/mottled & Andean & Nueva Granada & 3.11 & 0 & 5.84 & 17 \\
Great northern & Middle American & Durango & 0.94 & 0 & 2.12 & 31 \\
Pink & Middle American & Durango & 2.48 & 0 & 6.37 & 23 \\
Pinto & Middle American & Durango & 0.74 & 0 & 2.38 & 93 \\
Black & Middle American & Mesoamerica & 17.63 & 19 & 13.22 & 43 \\
Navy/small white & Middle American & Mesoamerica & 15.2 & 8.5 & 16.62 & 46 \\
Red/small red & Middle American & Variable & 9.59 & 4 & 14.7 & 29 \\
\hline
\end{tabular}

\section{References}

1. Assefa T, et al. (2013). Pod harvest index as a selection criterion to improve drought resistance in white pea bean. Field Crops Res, 148, 24-33.

2. Dong $Y$, et al. (2014). Pod shattering resistance associated with domestication is mediated by a NAC gene in soybean. Nat Comm, 5, 3352 .

3. Song Q, et al. (2015). SNP assay development for linkage map construction, anchoring wholegenome sequence, and other genetic and genomic applications in common bean. G3 (Bethesda), 5(11), 2285-2290.

4. Broman KW, Wu H, Sen Ś, Churchill, GA (2003). "R/qtl: QTL mapping in experimental crosses." Bioinformatics 19(7), 889-890.

5. Goodstein DM, et al. (2011). Phytozome: a comparative platform for green plant genomics. Nucleic Acids Res, 40(D1), D1178-D1186.

6. Li J, Dai X, Zhuang Z, Zhao PX (2016). LegumelP 2.0—a platform for the study of gene function and genome evolution in legumes. Nucleic Acids Res, 44(D1), D1189-D1194.

7. McClean PE, Mamidi S., McConnell M, Chikara S, Lee R (2010). Synteny mapping between common bean and soybean reveals extensive blocks of shared loci. BMC Genomics, 11(1), 184.

8. Schmutz J, et al. (2014). A reference genome for common bean and genome-wide analysis of dual domestications. Nature Genetics, 46(7), 707.

9. Lyons E, Pedersen B, Kane J, Freeling M (2008). The value of nonmodel genomes and an example using SynMap within CoGe to dissect the hexaploidy that predates the rosids. Trop Plant Biol, 1(3-4), 181-190.

10. Schmutz J, et al. (2010). Genome sequence of the palaeopolyploid soybean. Nature, 463(7278), 178.

11. Desper R, Gascuel O (2004). Theoretical foundation of the balanced minimum evolution method of phylogenetic inference and its relationship to weighted least-squares tree fitting. Mol Biol Evol, 21(3), 587-598.

12. O'Rourke JA et al. (2014). An RNA-Seq based gene expression atlas of the common bean. BMC Genomics, 15(1), 866.

13. Papadopoulos JS, Agarwala R (2007). COBALT: constraint-based alignment tool for multiple protein sequences. Bioinformatics, 23(9), 1073-1079. 
14. Choi Y, Chan AP. "PROVEAN web server: a tool to predict the functional effect of amino acid substitutions and indels." Bioinformatics 31.16 (2015): 2745-2747.

15. Cichy KA et al. (2015). A Phaseolus vulgaris diversity panel for Andean bean improvement. Crop Sci, 55(5), 2149-2160.

16. Moghaddam SM, et al. (2016). Genome-wide association study identifies candidate loci underlying agronomic traits in a Middle American diversity panel of common bean. Plant Genome, 9(3).

17. Bradbury PJ, et al. (2007). TASSEL: software for association mapping of complex traits in diverse samples. Bioinformatics, 23(19), 2633-2635.

18. Dereeper A, et al. (2011). SNiPlay: a web-based tool for detection, management and analysis of SNPs. Application to grapevine diversity projects. BMC Bioinformatics, 12(1), 134.

19. Turner SD (2018). qqman: an R package for visualizing GWAS results using $Q-Q$ and manhattan plots. J Open Source Softw, 3(25), 731.

20. Fick SE, Hijmans RJ (2017). WorldClim 2: new 1-km spatial resolution climate surfaces for global land areas. Intl J Climatol, 37(12), 4302-4315.

21. Kelso NV, Patterson T (2010). Introducing natural earth data-naturalearthdata. com. Geographia Technica, 5, 82-89.

22. Soltis PS, Soltis DE, Savolainen V, Crane PR, Barraclough TG (2002). Rate heterogeneity among lineages of tracheophytes: integration of molecular and fossil data and evidence for molecular living fossils. Proc Natl Acad Sci, 99(7), 4430-4435.

23. Zimmer A, et al. (2007). Dating the early evolution of plants: detection and molecular clock analyses of orthologs. Mol Genet Genomics, 278(4), 393-402.

24. Kim KW, et al. (2015). Trimeric structure of (+)-pinoresinol-forming dirigent protein at $1.95 \AA$ resolution with three isolated active sites. J. Biol Chem, 290(3), 1308-1318.

25. Gasper R, et al. (2016). Dirigent protein mode of action revealed by the crystal structure of AtDIR6. Plant Physiol, pp-01281. 